\title{
anemon
}

Muş Alparslan Üniversitesi Sosyal Bilimler Dergisi

Journal of Social Sciences of Muş Alparslan University

Yı//Year: 2017 • Cilt/Volume: 5 • Sayı/Number: 1

ISSN: 2147-7655 • e-ISSN: 2149-4622

ÖZGÜN ARASTTIRMA O ORIGINAL ARTICLE

\section{Üniversiteler Kendini Nasıl Tanımlıyor? Üniversite Tanıtım Filmleri Üzerine Söylem Analizi}

\author{
Doğan AYDOĞAN ${ }^{1, a}$, Mustafa Halid KARAARSLAN ${ }^{2}$ \\ ${ }^{1}$ Yrd. Doç. Dr., Karabük Üniversitesi, İșletme Fak., Halkla İlişkiler ve Tanıtım Bölümü- Karabük / Türkiye
${ }^{2}$ Yrd. Doç. Dr., Karabük Üniversitesi, İșletme Fak., Uluslararası İssletme Bölümü- Karabük / Türkiye
}

Başvuru tarihi: 23 Ağustos 2016 Düzeltme tarihi: 16 Aralık $2016 \quad$ Kabul tarihi: 30 Ocak 2017

Öz

Küreselleşen dünyada bilgi ve üniversite kavramları da hızla küreselleşmekte ve üniversiteler bu etkileşime uyum sağlamak durumunda kalmaktadır. Bu durum öğrenci hareketliliğine de yansımakta ve küresel bir rekabete dönüşmektedir. Türkiye'de son yıllarda birçok üniversitenin açılmış olması bu çerçevede daha fazla çaba harcanması gerekliliğini göstermektedir. 2000 yılında 73 olan üniversite sayısı süreç içinde hızla artmıştır. Bu durum ulusal ve küresel rekabete yansımakta, üniversitelerin tanıtım faaliyetlerini daha rekabetçi bir yapıya sokmaktadır. $\mathrm{Bu}$ çalışmada toplam 6 üniversite seçilerek üniversitelerin hazırladıkları ve kurumsal hesaplarında yayınladıkları tanıtım filmleri üzerine söylem analizi yapılmıştır. Üniversiteler 2000 yılı öncesinde/sonrasında kurulan; büyükşehirde/büyükşsehir haricinde kurulu ve devlet/vakıf üniversitesi şeklinde sınıflandırılmıştır. Sonuç olarak üniversiteler için belirlenen ayrımların, onların mesajlarının farklılaşması üzerine anlamlı sonuçları olduğu görülmüştür. Araştırma sonuçları ile ilgili üniversitelere pazarlama önerilerinde bulunulmuştur.

\section{Anahtar Kelimeler}

Üniversite, Pazarlama, Göstergebilim, Söylem Analizi, Kurumsal Kimlik

\footnotetext{
a Sorumlu Yazar/Correspoding Author: Karabük Üniversitesi, Demirçelik Kampüsü, Kardemir Blok A Girişi, İşletme Fakültesi, Kat: 2, 78050, Karabük /Türkiye.

e-posta: doganaydogan@karabuk.edu.tr 


\title{
How Universities Identify Themselves? Discourse Analysis About University Promotional Films
}

\begin{abstract}
In globalized world, knowledge and university notions are being globalized and universities have to adapt to this interaction. This situation is also reflected in student mobility and turns into a global competition. In this context, more effort should be spent because of many universities' having been established in Turkey in the last few years. The number of 73 universities in 2000 increased rapidly in the process. This reflects the national and global competition, making the promotional activities of universities more competitive. In this study universities were classified in three categories; established before 2000/after 2000; established in urban-rural; state or foundation university. A total of 6 universities were selected in this study and discourse analyzes were made on the publicity films prepared by the universities and published in their institutional accounts. As a result, the distinctions established for the universities have been found to have meaningful implications on the differentiation of their messages. The marketing suggestions have been made to the universities regarding the research results.
\end{abstract}

\section{Keywords}

University, Marketing, Semiotics, Discourse Analysis, Corporate Identity

\section{GIRISs}

1980’lerden itibaren yükseköğretimin yaygınlaştırılması politikası çerçevesinde, vakıf üniversiteleri açılmış, ikinci öğretim, açık öğretim gibi seçeneklerle yükseköğretimde okuyan kişi sayısının arttırılması hedeflenmiştir, ayrıca büyükşehirler dışına da devlet üniversiteleri açılmıștır (Kavak, 2011: 100). Türkiye'de 1984 yılında ilk vakıf üniversitesi kurulduğunda devlet üniversitelerinin sayısı 27 adettir (Günay ve Günay, 2011: 7). 2016 yılı itibarı ile Türkiye'de 109 adet devlet üniversitesi, 76 adet vakıf üniversitesi ve 8 adet vakıf meslek yüksekokulu bulunmaktadır (YÖK, 2016).

Dünya'da üniversiteler ilk ortaya çıktıklarında "eğitim" yönleri ağır basmıştır, sanayi devrimi ile birlikte "araştırma" yönleri ağırlık kazanmış şimdi ise "girişimci" üniversiteler ekonomik ve sosyal kalkınmada doğrudan katkı sunmayı hedeflemektedir (Sakınç ve Bursalıŏlu, 2012: 93). Bu da üniversitelerin sosyal ve ekonomik yaşamla daha yakın bir ilişki kurmasını gerekli kılmaktadır.

Türkiye'de üniversiteye kayıtlı öğrenci sayısı 6.062.886'dır (YÖK, 2016). Üniversite sayıları ve kontenjanlarının artması ile birlikte üniversiteler arasında rekabet belirgin hale gelmiştir. Tüm üniversiteler daha iyi öğrencileri alabilmek için yarışa girmiştir. Köklü üniversiteler en yüksek puana sahip öğrencilerin tercih devamlılığını sağlamaya çalışırken, yeni kurulan üniversiteler ise yüksek puanlı öğrencileri kendilerini tercih 
etmeleri için ikna etmeye çalışmaktadır. Üniversitelerin bazı bölümleri ise kapanmama mücadelesi vermektedir. Bu çerçevede üniversiteler farklılaşma ve uzmanlaşma yoluna giderek; bu süreçte kurumsal kimlik çalışmalarına ağıllık vermektedir. Özellikle son yıllarda hızla artan üniversite sayısı, kurumsal kimlik oluşturma ve tanıtım faaliyetlerini çok daha önemli hale getirmiştir. Üniversitelerin pazarlama faaliyetlerinin artmasına paralel olarak üniversite pazarlaması ile ilgili akademik çalışmalar son yıllarda artış göstermektedir (Yenen ve Gözlü, 2003; Hemsley-Brown ve Oplatka, 2006; Okumuş ve Duygun, 2008; Newman ve Jahdi, 2009; Binbaşıŏlu, 2011; Marangoz ve Arslan, 2015). Üniversiteler, tüketici ya da hedef kitlenin doğrudan yaşam planını biçimlendiren örgütler olduğu için, oluşturdukları kurumsal itibar ve imaj son derece önemlidir. Kitlenin doğrudan ya da dolaylı olarak aldığı mesajlar toplamı kurumların itibarını oluşturur (Vural ve Bat, 2013; 128). Bu nedenle üniversitelerin uzun vadede kurumsal marka konumlandırmasını yapması ve iletişim politikalarını bu çerçevede biçimlendirmesi gerekmektedir.

İşletmeler pazarlama mesajlarını rekabette "en avantajlı konumu" elde etmek için geliştirmektedir (Trout, 2005 :27). Bu sebeple konumlandırma yapılırken işletme kendini rakiplerden farklılaştırmalıdır. Bu farklılaştırmanın koruma sağlayabilmesi için kolaylıkla taklit edilememesi gerekir (Altunışık, Özdemir ve Torlak, 2016: 230). Bu sebeple tanıtımında kullanacağı vaatler rakiplerininkinden farklı olmalı ve tüketicinin var olan algıları ile uyumlu olmalıdır. Yeni bir üniversitenin Türkiye'nin en iyi üniversite iddiası algı ile uyumlu olmadı̆̆ 1 için başarılı sonuç vermesi mümkün değildir. Kurumsal itibarın aşamalı olarak bir strateji çerçevesinde geliştirilmesi gereklidir.

Pazarlama faaliyetleri temelde müşterilere en iyi değeri sunabilmek için yapılır. Müşterilerin elde ettikleri faydaların katlandıkları maliyetlerden fazla olduğunu düşünmelerine algılanan müşteri değeri denir (Kotler ve Keller, 2009: 160). Müşteri için değer yaratma, müşterinin neleri istediği ve ürünü satın alıp kullandıktan sonra neyi elde ettiği ile ilgilidir (Tekin ve Çiçek, 2005: 66). Bu sebeple üniversiteler daha tercih edilir olmak için öğrencilerin beklentilerini öğrenmekte ve bu beklentileri ne oranda karşılayabildiklerini ölçmektedirler. Ayrıca başarılı öğrencilere çeşitli burslar ve hediyeler vererek öğrencilerin tercihini etkilemeye çalışmaktadır. Hem devlet üniversiteleri hem de vakıf üniversiteleri kendilerini tanıtabilmek için ciddi çaba ve kaynak harcamaya başlamışlardır.

Yücebaş (2011), üniversite kavramı ile reklam kavramı arasındaki ilişkiyi inceleyen çalışmasında; üniversitelerin yaptığı reklamların öğrencilerin üniversite ile olan ilişkilerini "sıradan bir alışveriş esnasında olduğu gibi, maksimum faydayı sağlayacak etkinlikte geçmeli, ögrencilerin yaşam deneyimlerinde muhakkak paraya, işe ve gelecekte kullanılabilecek bir pratik yarara tahvil edilebilir" niteliğe dönüştürdüğünü belirtmektedir. Üniversitelerin gazete ve dergilere verdiği ilanlarda en çok yurt dışı olanakları, kariyer olanakları, burslar ve nitelikli eğitim vaat ettikleri bulunmuştur (Yıldız, 2014: 166). Üniversiteler küreselleşmenin getirdiği hızlı ve rekabetçi gelişmelerden etkilenmekte ve söylemlerini bu şekilde kurmaktadır. Üniversiteler tanıtımlarında en çok gelecek, dünya, başarı ve tercih kelimelerini kullanmıştır (Yıldız, 2014: 165). 
Bu bağlamda çalışmanın amacı Türkiye'deki üniversitelerin kendilerini nasıl tanımladıkları ve tanıtım faaliyetlerinde ürettikleri söylemin tespit edilmesidir. $\mathrm{Bu}$ sebeple 6 üniversitenin tanıtım filmi incelenmiştir. Üniversitelerin tanıtım filmlerinin seçilme gerekçesi, tanıtım filmlerinin çok sayıdaki kişiye ulaşması, mesajın oluşturulmasındaki tüm kontrolün üniversitede olması, görsel ve işitsel mesajların birlikte kullanılabilmesidir. İnternet hızla gelişerek özellikle sosyal medyanın etkisi ile büyük bir pazarlama ve reklam kanalına dönüşmüştür. Ayrıca internet tanıtımlarında yayıncıya komisyon ödemek zorunda olmamak, içeriği hızlı bir şekilde değiştirebilmek, hızlı geri bildirim almak ve geniş bir coğrafyada bölünmüş pazarlara hitap edebilme olanakları bulunmaktadır (Babacan, 2015: 117-118). Bu gibi olanaklar internet üzerinden yapılan tanıtım ve reklam faaliyetlerini üniversiteler için kullanışlı hale getirmektedir. $\mathrm{Bu}$ çerçevede üniversiteler kendilerini anlatırken tanıtım filmlerinde diğer tanıtım araçlarına göre daha fazla seçeneğe sahip olabilmektedirler. Araştırmanın sonuçlarında üniversitelerin pazarlaması üzerine çalışacak araştırmacılara ve üniversitelerin tanıtımı konusunda çalışan uygulamacılara öneriler bulunmaktadır.

\section{YÖNTEM}

Üniversiteler “devlet üniversitesi/vakıf üniversitesi”, büyükşehirlerde kurulan, büyükşehirler haricinde kurulan ve 2000 y1lı öncesinde kurulan-2000 y1lı sonrasında kurulan olmak üzere üç niteliğe göre sekiz kategoriye ayrılmışlardır (Tablo 1). Üniversitelerin ilk ayrımı üniversitenin devlet veya vakıf üniversitesi olmasına göredir. Üniversitelerin devlet ve vakıf üniversitesi olması üniversitelerin tanıtıma ayırabileceği bütçeyi, öğrencilere üniversiteyi tercih etmeleri için önereceği faydaları etkileyecektir. İkinci ayrım ise üniversitenin kuruluş tarihidir. $\mathrm{Bu}$ ayrım ise üniversitenin köklü bir üniversite olarak görülmesini etkileyebilir. Bu durum yeni kurulan üniversitelerin öğrencilerde bilinirlik oluşturmak ve tercih edilebilmek için kuruluşu daha eskiye dayanan üniversitelerden farklı bir söylem üretmesine yol açabilir. Üçüncü ayrım ise üniversitenin kurulduğu şehrin büyüklüğüdür.

Tablo 1. Üniversitelerin Kategorilere Göre Ayrımları ve Her Kategoriden Seçilen Üniversite

\begin{tabular}{|c|c|c|c|c|}
\hline & \multicolumn{2}{|c|}{ Devlet Üniversitesi } & \multicolumn{2}{|c|}{ Vakıf Üniversitesi } \\
\hline Kuruluş & 2000 öncesi & 2000 sonras1 & 2000 öncesi & 2000 sonras1 \\
\hline $\begin{array}{c}\text { Büyükşehir } \\
\text { (Üniversite sayıs1) }\end{array}$ & (43), ODTÜ & $\begin{array}{l}\text { (18), Bursa } \\
\text { Teknik Üni. }\end{array}$ & $\begin{array}{l}\text { (20), Koç } \\
\text { Üni. }\end{array}$ & $\begin{array}{c}\text { (56), Hasan } \\
\text { Kalyoncu Üni. }\end{array}$ \\
\hline $\begin{array}{l}\text { Büyükş̧ehir dışı } \\
\text { (Üniversite sayısı) }\end{array}$ & $\begin{array}{l}\text { (10), Cumhuriyet } \\
\text { Üni. }\end{array}$ & $\begin{array}{l}\text { (38), Yalova } \\
\text { Üni. }\end{array}$ & 0 & 0 \\
\hline
\end{tabular}

Araştırmada üniversitenin kurulu olduğu şehrin 2016 yılında büyükşehir olup olmamasını göz önünde bulundurulmuştur. Öğrencilerin üniversite seçimlerini şehrin büyüklüğüne ve imkânlarına göre yaptıkları varsayılmıştır. Büyükşehirlerde kurulan üniversiteler diğerlerine göre pek çok yönden daha avantajlıdır. İlk olarak şehrin imkânları ve bilinirliği onların tercih edilmesini kolaylaştırmaktadır. Buna ek olarak büyük şehirlerde yaşayan ve şehir dışına çıkma isteği bulunmayan büyük bir nüfusun önceliği bulundukları şehirlerdeki bu üniversiteler olmaktadır. Büyükşehirler haricinde kurulan vakıf üniversitesi bulunmadığı için iki kategoriye ait üniversite bulunmamaktadır. Her bir 
gruptan bir üniversite seçilerek toplamda 6 üniversite seçilmiştir. Seçim işlemi her bir gruptan bir üniversite olacak şekilde yargısal olarak belirlenmiştir. İncelenen tanıtım filmleri, çalışma esnasında üniversitelerin kendi internet sitelerinde veya üniversitelerin kurumsal sosyal ağlarında güncel olarak yayında olan tanıtım filmleridir.

\subsection{Araştırmanın Kısıtları}

Araştırma Türkiye'de bulunan tüm üniversiteleri temsil kabiliyetinde değildir. Örneklem grubunu oluşturan altı üniversite birbirinden farklı özelliklere sahip şehirlerden seçilerek olabildiğince çeşitlilik ve temsil gücü sağlanmaya çalışılmıştır. Araştırma 2016 y1lı haziran ayında üniversitelerin kurumsal internet sitelerinden ulaşılabilen tanıtım filmlerinden oluşmaktadır. Üniversiteler genellikle her yıl veya iki yılda bir tanıtım filmi hazırlatmaktadır. Üniversiteler kendilerini tanımlarken çok farklı mecralar kullanmaktadır ve bu mecralarda verilen mesajların içerikleri tam olarak bir diğeriyle örtüşmeyebilmektedir.

\section{2. İnceleme Yöntemi - Göstergebilim ve Söylem Analizi}

Günümüz dünyası görsel iletişimin hâkim olduğu bir kültüre sahiptir. Gündelik yaşam tüketici olarak konumlandırılan bireyler için düzenlenmiş sayısız görsel metinle doldurulmuş, bireyler ise günlük rutinleri içinde bu metinlere bilinçli, istekli veya istemleri dışında ve bilinçsiz olarak maruz kalmaktadır. Özellikle sosyal medyanın yaygınlaşmasının ardından görsel mesajlarda niceliksel bir artış olmuş, kurgusal içerik ile belgesel içerik, reklam amaçlı üretilmiş metinle sıradan bir metin birbiri ile iç içe geçmiştir. Görsel iletişimde ve reklam platformlarında kitle iletişim araçlarının baskınlığı azalmıştır. Özellikle davranışsal reklamcılık uygulamaları ile sosyal medya üzerinde doğru hedef kitleye ulaşmak çok daha kolay hale gelmiş ve akıllı telefonlarla birlikte hızla gelişen dijital reklam medyaları, bu mecralar için üretilen içerikleri belirgin biçimde önemli hale getirmiştir. Üniversiteler artan oranda sosyal medya üzerinden gençlere yönelik reklam ve tanıtım faaliyetleri gerçekleştirmekte, dijital ortamlarda yapılan tanıtımlar, gençler ile üniversiteler arasında önemli bir iletişim sağlamaktadır.

Her türlü görsel metin bir kodlamayı dolayısıyla bir söylemi barındırır. Ancak bu çalışmada reklam filmleri yerine tanıtım filmleri incelenmiştir. Çünkü her ne kadar tanıtım filmleri de bir dizisellik (seçme) ve dizimsellik (birleştirme) sürecini, dolayısıyla kurguyu barındırsa da reklam filmlerinin kurgusal yapısına oranla izleyicide belgesel formuna daha yakın bir tür/anlatı izlenimi uyandırmaktadır. Bu nedenle tanıtım filmlerinin gerçeklikle ilişkisi daha az sorgulanmaktadır.

$\mathrm{Bu}$ bağlamda örneklem kümesini oluşturan üniversitelerin internet siteleri incelenmiş, üniversite sitelerinde fiilen yayında olan filmler dışında herhangi bir metin kullanılmamıştır. $\mathrm{Bu}$ filmler üniversitelerin kurumsal sitelerinden veya buradan bağlantı verilen kurumsal sosyal medya hesapları üzerinden indirilerek, işlevsel/tematik kareleri ayırt edilmiş ve göstergelerin analizi yoluyla anlam ortaya çıkarılmıştır.

Göstergebilim, dilbilimci Saussure tarafından ortaya konmuş yapısalcı bir metin analiz yöntemidir. Metnin yapısal unsurlarına bölünerek anlamın ortaya çıkarılabileceğini 
savunan Saussure, çalışmalarını dilbilim çalışmalarında yoğunlaştırmıştır. Yapısalcı çalışmalarla birlikte gelişen göstergebilim, altmışlı yıllardan itibaren dil ve söyleme yönelik yoğunlaşan çalışmalarda birçok araştırmacı tarafindan ele alınmış ve görsel metinlerin analizinde yaygın olarak kullanılan bir yöntem olarak kabul edilmiştir (Sözen, 2013).

Bir iletişim unsuru olarak gösterge, gösteren ve gösterilen olarak ikiye ayrılır. Kodlanmış bir mesaja dönüşen gösteren, nesne olarak bir gösterileni işaret eder. Ancak göstergede kullanılan diğer kodlar (kamera açısı, renk, bağlam v.b.) göstereni diğer göstergelerle ilişkiye sokarak, düz anlamın yanına anlamı zenginleştiren yan anlamları, kültürel kodları, alegori ve metonimileri ekler. Böylece bir gösteren yayılan bir söylemin parçası haline gelir ve farklı bağlamlarda farklı anlamlar üretir. Bu nedenle göstergebilimciler metni sabit bir kavram olarak değil, kodlayıcı, metin ve kod açıcı arasında bir müzakere olarak adlandırmıştır. Metni oluşturan göstergeler paradigması ve düzenleniş biçimleri göstergebilimin inceleme alanıdır (Fiske, 2013; 121-130).

Söylem ise baskın kültürün ve düşünce biçiminin kendini değişik metinlerde ifade ediş biçimidir (El-Nawawy \& Elmesry, 2016). Büyük anlatılar doğrudan anlatım yoluyla üretilmezler, sosyokültürel yaşamın değişik yönlerine dağılarak farklı öznelerin metin kurma biçimlerinde tekrar üretilirler. Göstergebilim bir metinde ne söylendiğine yoğunlaşırken, söylem analizi bir düşüncenin kendini mikro düzeyde nasıl ifade ettiğine yoğunlaşmaktadır. Bu bağlamda göstergeler bu ifade ediş biçiminin ürünüdür, bu nedenle bir bağlamda ele alınmalıdır. Söylem sadece söylenende değil, mesajların oluşturduğu tematik bütünlüklerde ortaya çıkar. Bütün özneler "BİZ” kurgusunu örerken kendi olumlu niteliklerini ön plana çıkaracaktır bu da kendini en fazla temalarda ele vermektedir. $\mathrm{Bu}$ bağlamda anlamı oluşturan ikinci söylem unsuru tanım düzeyi ve ayrıntı derecesidir. Bütün özneler kendi olumlu yönlerini daha iyi tanımlamak ve daha ayrıntılı anlatmak eğilimindedir. Bu ayrıntı bütünleri de tematik parçaları oluşturur (Dijk, 2015: 55).

Söylemlerin kurumsal kimlik oluştururken üyelerine belirli cevaplar üretmesi gerekmektedir. Kurum kimliği ancak üretilen bu söylemin ördüğü "BİZ” kavramının belirginliği ile aktarılabilir. Söylemler şu soruları cevaplayarak varlıklarını güçlendirir;

(i) Üyelik ölçütleri: Kimler ait (değil)?

(ii) Tipik etkinlikler: Ne yapıyoruz?

(iii) Genel amaçlar: Ne istiyoruz? Bunu niçin yapıyoruz?

(iv) Kurallar ve değerler: Bizim için iyi ya da kötü olan nedir?

(v) Durum: Ötekilerle ne tür ilişkilere sahibiz?

(vi) Kaynaklar: Kim(ler) grup kaynaklarımıza ulaşma hakkına sahip (Dijk, 2015: 28)? Bu soruların net olarak cevaplanışı grup kimliği ve davranış modelinin ortaya çıktığını göstermektedir.

$\mathrm{Bu}$ bağlamda tanıtım filmleri incelenirken, iletişim esnasında belirtilmeyen herkesin biliyor kabul ettiği ortak alana ait içerikler incelenmeyecektir. Bunun yerine söylem bazında tematik bütünlükleri ve ayrıntı düzeyleri içinde önemli bir biçimde ayrışan bölümler ve bu bölümleri temsil edebilecek göstergeler incelenecektir. 


\section{3. ÜNIVERSITE TANITIM FILMLERININ İNCELENMESI}

\subsection{Orta Doğu Teknik Üniversitesi}

Tanıtım filmi (ODTÜ, 2014), Türk Bayrağı ile ODTÜ logosunun yer aldığı bayrağın birlikte dalgalanışı ile açılmaktadır (Resim 1). Alt açıdan gerçekleştirilen bu çekim bayrakları yüceltmekte, dalgalanma ve renklerin birlikteliği yüceltmenin yanı sıra ODTÜ ile Türkiye arasında sembolik bir bağ kurmaktadır. Milliyetçiliğin klasik bir tasviri olarak okunabilecek bu metin takip eden sekanslarda sürekli vurgulanan küresel değerler, metropol, ulus üstü eğitim ve hedefler gibi kavramla desteklenmekte ve milliyetçiliği daha sivil, evrensel değerleri destekleyen bir unsur olarak ön plana çıkarmaktadır. $\mathrm{Bu}$ söylem filmin açılışında yazıyla da vurgulanan "Bizler dünyayı değiştirebiliriz" sloganıyla özetlenmekte, "Biz" kavramı küresel hedefleri olan, evrensel bir dünyanın parçası olarak konumlandırılmaktadır.

Resim 1. Türk Bayrağı ve ODTÜ Logosu

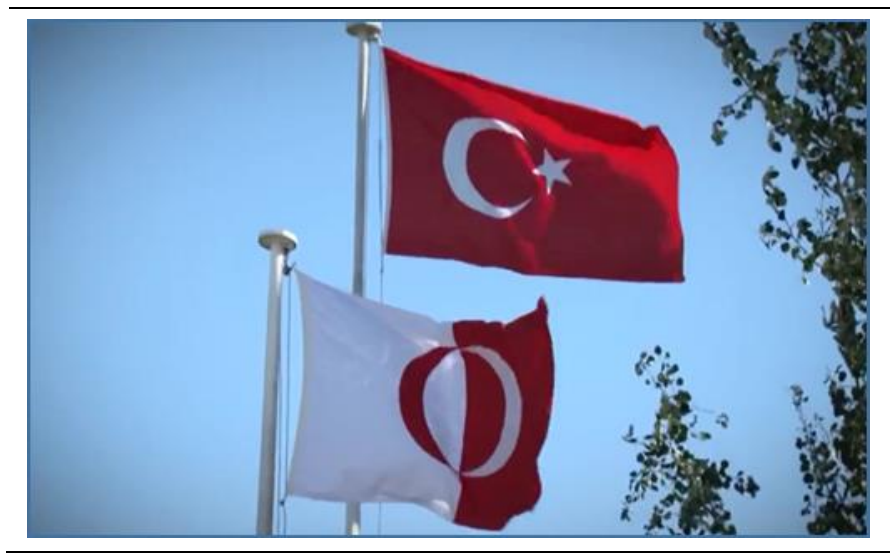

"Biz" kavramı anlatıda birçok yapısal unsurdan yararlanılarak üretilmekte ve hedef kitle ulus üstü bir coğrafyayı kapsayacak şekilde genişletilmektedir. Bu noktada sesin ve anlatıcının konumlandırılışını özellikle incelemek gerekmektedir. Filmde anlatıcı olarak dış ses yalnızca sekansların açılış sahnelerinde kullanılmıştır. Bunun dışında anlatıcı olarak dış ses kullanılmamış üniversitenin paydaşları olarak öğrenciler ve öğretim üyeleri özne konumuna geçirilmiş, anlatım onların üzerinden gerçekleştirilmiştir. Öğretim üyeleri ve öğrencileri anlatıcı olarak kullanan anlatı yapısı, dış sesin nesneleștirici ve yabancılaş̧ırıcı etkisinden kurtulmuş ve daha eşitlikçi bir söylem oluşturmuştur. Biz kavramı sadece öğretim üyelerini ve öğrencileri özne olarak kullanmamış, özneler arasında da eşitlikçi bir yapı sergilenmeye özen gösterilmiştir. Öğrenci ve öğretim üyelerinin anlatıcı olarak kullanıldığı sahnelerde gerek cinsiyet gerek uyruk açısından "biz" kavramı eşitlikçi ve ulus üstü bir konumda kullanılmıștır. 
Resim 2. Yabancı Uyruklu Öğretim Üyesi

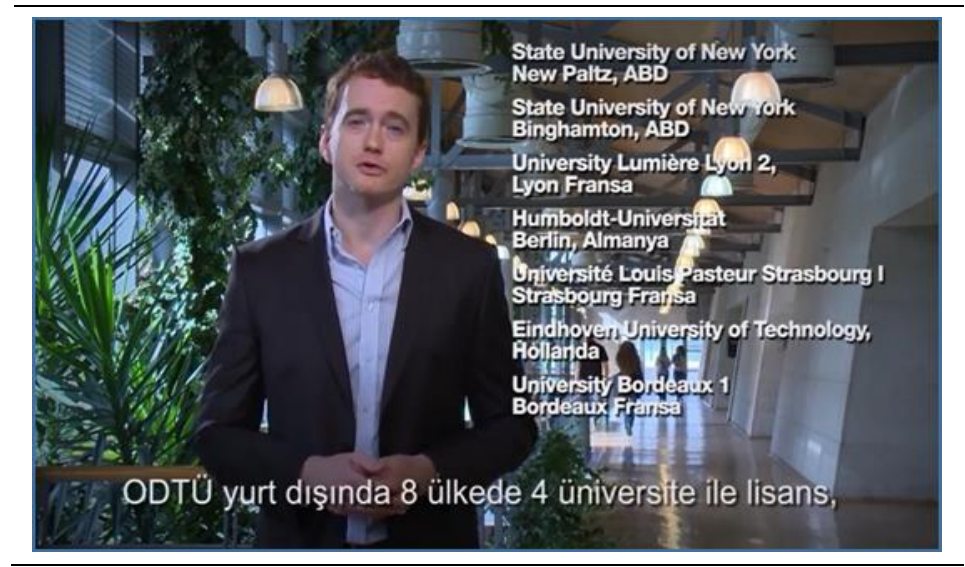

Resim 2'de görüldüğg̈ gibi ODTÜ'yü anlatan "biz" kavramı örülürken yabancı uyruklu bir öğretim üyesi, İngilizce konuşmaktadır. Bu göstergede gösterilenin düz anlamı yabancı uyruklu öğretim üyesi iken, gösterilenin yan anlamı ulus üstü değerleri ve evrenselliği betimlemektedir. Benzer söylemleri öğrencilerin üniversiteyi anlattığı sahnelerde de görmek mümkündür. Anlatım esnasında ses ile aktarılan uluslararası eğitim, projeler, programlar, öğretim üyesi yetiştirme gibi unsurlar çekimlerde fotografik olarak sürekli desteklenmiştir. Resim 2 ve Resim 3 birlikte incelendiğinde her iki göstergede de benzer bir yapısal dilin kullanıldığı görülmektedir. Her iki kullanımda da yabancı uyruklu özneler ODTÜ yerleşkesinde yaşanan gündelik yaşamın sıradanlığı içinde çerçevelenmiş ancak alan derinliği bir anlatım unsuru olarak ön plana geçmiştir. Diyaframın açık kullanılması ile bilinçli olarak daraltılan net alan bölgesi, fotoğraf dilinde önemli bir yapısal unsurdur. Diğer alanları bulanıklaştırarak, bakılması ve görülmesi gereken alanı vurgulayan bu yöntem fotoğraf dilinin en önemli anlatım araçlarından biridir. Her iki uygulamada da alan derinliği dar tutulmuş böylece yabancı uyruklu ODTÜ'lüler nesnel konumları içinden ayrıştırılarak vurgulanmıştır.

Resim 3. Yabancı Uyruklu Öğrenci

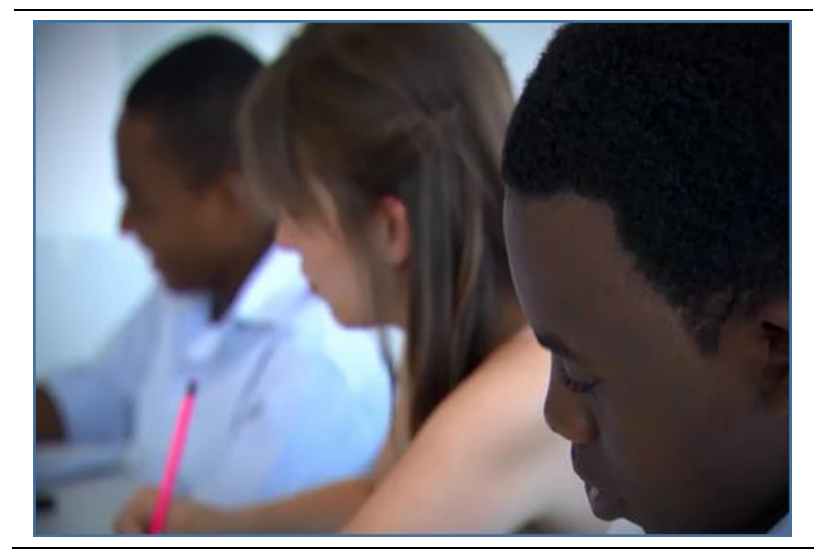


Filmin açılışında "bilgi ve öğrenme metropolü” sloganıyla daha önce de bahsedilen ulus üstü ve kozmopolit değerlere atıf yapan söylem, ODTÜ kimliğini oluştururken geçmişe ve köklülüğe yaptığı vurgu ile kurumsal kimliğini topluma ve tarihe yaslamaktadır. "Bilgi ve öğrenme metropolü” sloganının belirsiz zaman ve coğrafyası hemen arkasından gelen “1956'dan beri” cümlesi ile tamamlanmakta ve ODTÜ'nün tarihsel ve toplumsal boyutlarına vurgu yapılmaktadır. Resim 4'te anlam oluşturan unsur fotoğrafın siyah beyaz oluşudur. Göstergenin düz anlamı bir araya gelmiş bilim insanları iken, siyah beyaz fotoğrafın ürettiği yan anlam tarihselliğe vurgu yapmakta ve ODTÜ'nün köklü geçmişini vurgulamaktadır. Filmin biçimsel söylemi tam olarak bu köklü geçmiş ile evrensel değerlerin bir arada olmasından doğmakta ve bu söylem sürekli vurgulanmaktadır. Resim 5, geçmiş ve gelecek ile filmin başında vurgulanan sivil milliyetçiliği bir araya getirmektedir. ODTÜ yerleşkesinde yer alan müze ve koleksiyonların anlatıldığı karede bu ana kadar bahsedilen bütün göstergeler bir araya gelerek filmin söylemine eklenmektedir. Bir kadın anlatıcının arkasında Türkiye modernleşme sürecinde sembolik değeri çok yüksek olan göstergeler kullanılmıştır. Bu göstergelerin, gösterileni olarak Devrim arabaları tarihselliğe ve köklülüğe vurgu yapmaktadır. Sağ tarafta yer alan beyaz aracın plakasında "TECRÜBE" yazmakta ve bu düz anlamı desteklemektedir. Ancak Devrim Arabaları sıradan iki araç ve koleksiyon unsuru olmanın ötesinde metaforik anlamlar barındırmaktadır. Bu göstergelerin yan anlamı; modernleşme çabası, ağır sanayi hamleleri ve dünyada merkez ülkeler konumuna yükselme arzusunu barındırmakta ve modernleşmeci cumhuriyetin temel motivasyonunu yansıtmaktadır. ODTÜ’ de bu süreçte kendini lokomotif olarak konumlandırmaktadır. Bu karede kullanılan kadın figürasyonu ile devrim arabalarının çağrışımları bir araya geldiğinde, gelenekten evrenselliğe uzanan bir sürecin, ODTÜ kimliği ile özdeşleştirildiği görülmektedir.

Resim 4. Gelenek Vurgusu

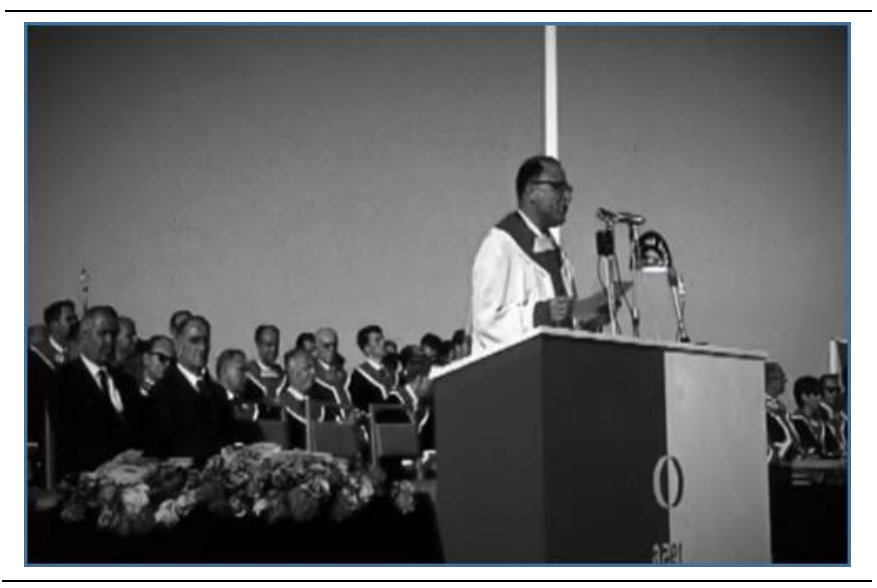

ODTÜ evrensel dünyaya, geçmişinden aldığı güç ile kurguladığı kozmopolit "biz" ile dâhil olmaktadır. Bu noktaya kadar geçmiş ile evrensel gelecek, paydaşlar ve özne olarak öğretim üyeleri ve öğrenciler arasında bir eşitlik ve denge, göstergeler aracılığı ile kurulmuştur. Film boyunca dengelenmeye çalışılan ve göstergelerle sürekli vurgulanan bir diğer unsur; teknoloji ve doğa birlikteliğidir. Film boyunca içerik olarak teknolojinin 
temsil edildiği Resim 6'ya benzer birçok karenin yer aldığı görülmektedir. Yüksek Teknolojiye dayalı laboratuvarlar, karmaşık kablolar, bilgisayarlarda yapılan karmaşık hesaplar. Resim 6'da da görüldüğü gibi alan derinliği bu tür çekimlerde bilgisayarı ve teknolojiyi vurgulayacak şekilde kısıtlanmakta, bilimsel çalışmanın yüksek teknolojiye dayalı doğası vurgulanmaktadır. Bu noktada bir diğer sinematografik unsur olarak kurgu ön plana geçmektedir. Dilbilim çalışmalarında tümce dizimi, kelimelerden bağımsız olarak söylemi oluşturan bir unsurdur (Dijk, 2015, s. 64). Buradan hareketle, dil kavramlarına benzetmek gerekirse çekimler kelime ise, kurgu bu kelimelerin sıralanış biçimidir ve filmografide anlamı oluşturan temel dinamiklerden biridir. Bütün film boyunca Resim 6'daki yapıya benzeyen yüksek teknoloji görüntülerini ya doğa içindeki etkinlik görüntüleri ya da Resim 2'deki gibi mimari, doğa ve 1şığın uyumunun vurgulandığı mimari niteliği ön planda olan çekimler takip etmektedir. Böylece salt iktisadi bir bilim ve teknoloji değil, insan ve doğayla uyum içinde olan bir teknoloji vurgulanmaktadır.

Resim 5. Devrim Arabaları ve Sergi

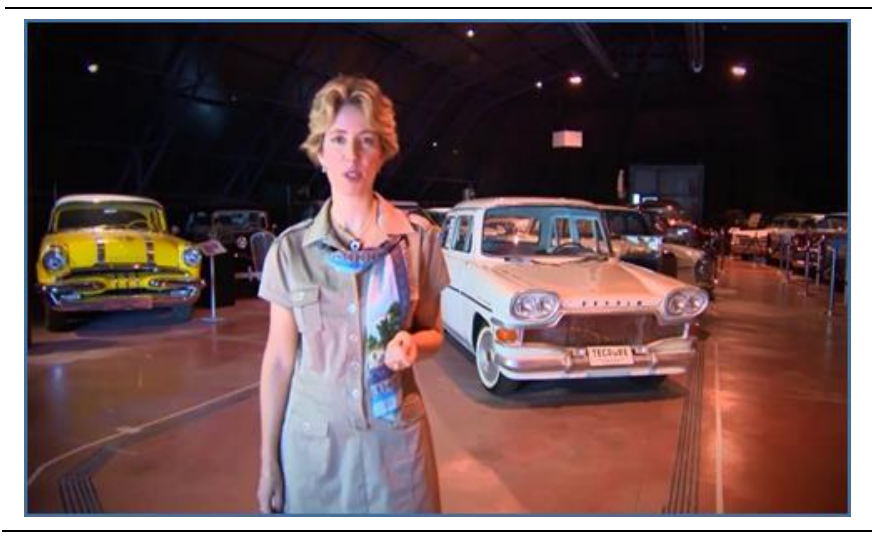

Resim 6. Yüksek Teknoloji

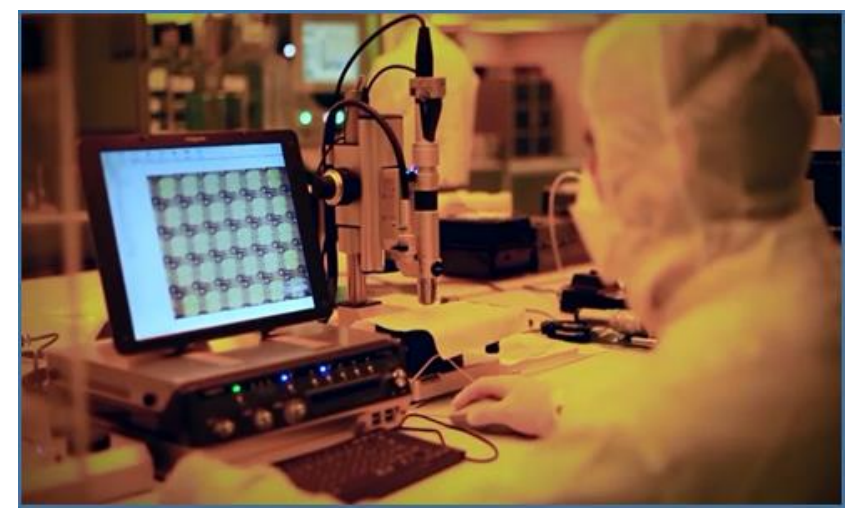


Özetlemek gerekirse, ODTÜ kurumsal kimliğini, köklü bir geçmiş ile evrensel değerlere dayalı bir kozmopolit gelecek arasında konumlandırmaktadır. Modernleşmeci milliyetçilik ile ODTÜ kimliği arasında tarihsel bir bağ kurulmakta, insana ve doğaya saygılı, sürdürülebilir bir modernlik vurgulanmaktadır. Filmde yansıtılmaya çalışılan bu temaların, filmografik anlatım unsurlarıyla da desteklendiği görülmektedir.

\subsection{Bursa Teknik Üniversitesi}

Bursa Teknik Üniversitesinin (BTÜ, 2015) tanıtım filminde de ODTÜ tanıtım filminde rastlanan kurumsal kimlik ile Türk Bayră̆ı'nı bir araya getirme uygulaması devam etmektedir. Ancak ODTÜ, Türk Bayrağı ile birlikte kendi ambleminin yer aldığı bayrağı kurumsal kimlik olarak kullanırken, BTÜ uygulamasında Türk Bayrağı ile kuruma ait bir binanın birlikte görselleştirildiği görülmektedir. $\mathrm{Bu}$ durum 2000 sonrası kurulan üniversitelerin tanıtım materyallerinde belirgin bir biçimde göze çarpmaktadır. Bina ve teknolojik altyapının vurgulanışı bir yeterliliği ispatlamaya çalışırken aynı zamanda yapılanma aşamasında oluşu da vurgulamaktadır. Bu durum film esnasında teknolojinin görselleştiriliş biçiminde de görülmektedir.

Resim 7. BTÜ ve Türk Bayrağ

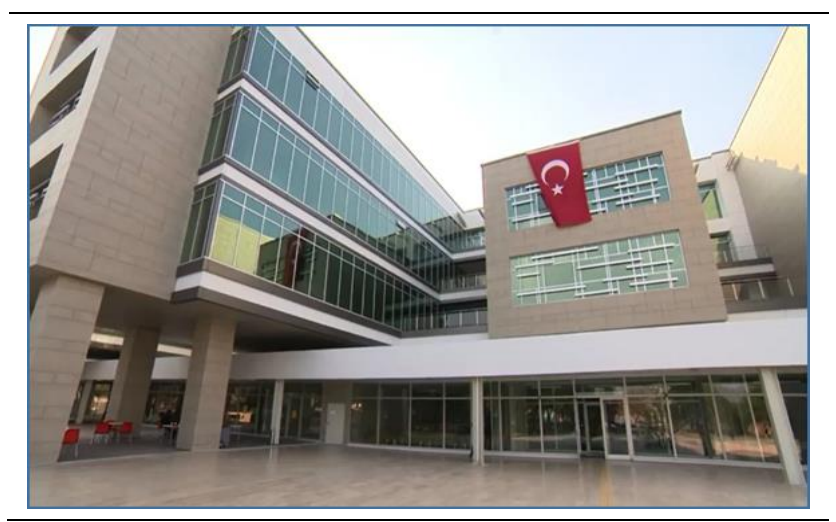

Resim 8'de belirgin bir biçimde görüldüğü gibi teknolojik aygit artzamanlı ya da eşzamanlı herhangi bir bağlama dâhil edilmeksizin, salt varlığı sebebi ile görselleştirilmektedir. Daha önce ODTÜ örneğinde teknolojinin kurgu yoluyla doğa ve insan ile ilişkilendirildiğini ve anlamın burada belirdiği belirtilmişti. Ancak Resim 8'de aygit tek başına yüceltilmekte, anlatılan unsur herhangi bir dizisel ya da dizimsel bağlama oturtulmamaktadır. Teknolojik cihazlar ve laboratuvarlar tanıtım filminin çeşitli yerlerinde dikkati çekmektedir. Teknoloji gösterimine özellikle bir vurgu söz konusudur. Bina ve teknolojik altyapıya yönelik bu vurgu daha önce de belirtildiği gibi 2000 sonrası kurulan birçok üniversitenin tanıtım materyalinde dikkat çekmektedir. 


\section{Resim 8. Teknoloji Gösterimi}

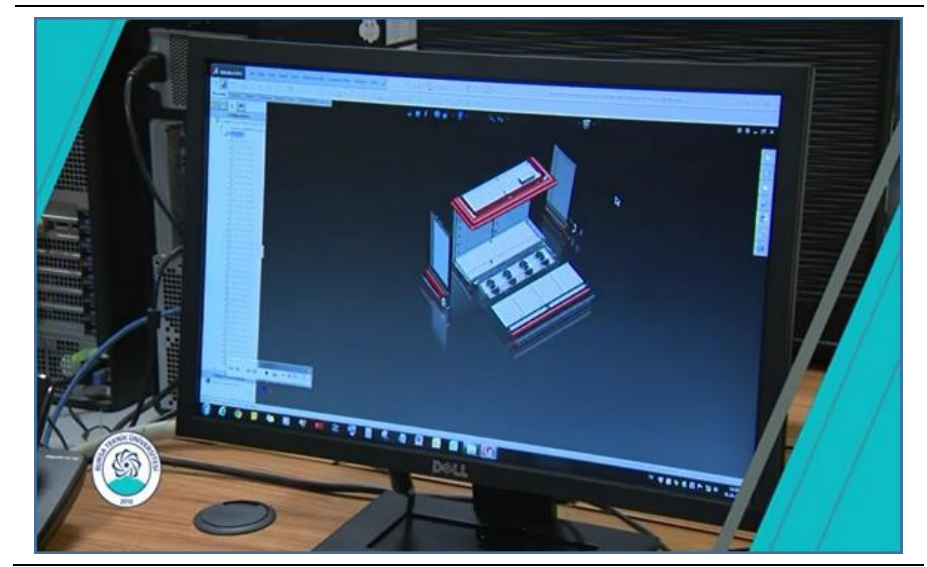

BTÜ tanıtım filminde dikkat çeken bir diğer unsur anlatımın şehrin olanakları ile başlamasıdır. Yeni kurulan birçok kurum henüz altyapı yatırımlarını tamamlama aşamasında olduğu için belirgin bir kurumsal kimliği bulunmamaktadır. Bu nedenle BTÜ (ve diğer yeni üniversitelerin) genel olarak anlatımlarına bulundukları şehrin tarihsel önemine ve var olan olanaklarını dâhil ettikleri, şehrin olanaklarını kurumsal kimliklerine dâhil etmeye çalıştıkları görülmektedir. Bu durum, metinde uydudan Türkiye'nin ve Türkiye'de Bursa şehrinin stratejik konumunu vurgulamaya yönelik bir görsel uygulama olarak karşımıza çıkmaktadır. Resim 10'da yine üniversiteden bağımsız olarak şehrin bir olanağının, kurumsal kimliğe aktarılma çabası belirmektedir. Bu uygulama ODTÜ örneği ile kıyaslandığında ağırlıklı olarak Ankara'da yerleşik olan ODTÜ'nün tanıtım filminde Ankara'dan ve başkentin olanaklarından hiç bahsetmediği, sadece kendi olanaklarını ön plana taşıdı̆̆ görülmektedir. Yeni kurulan üniversitelerin altyapı yatırımları tamamlandıkça, şehre yapılan vurgunun azalıp, yerleşkeye yapılan vurgunun artacağı öngörülebilir.

Resim 9. BTÜ ve Uydudan Görünüm

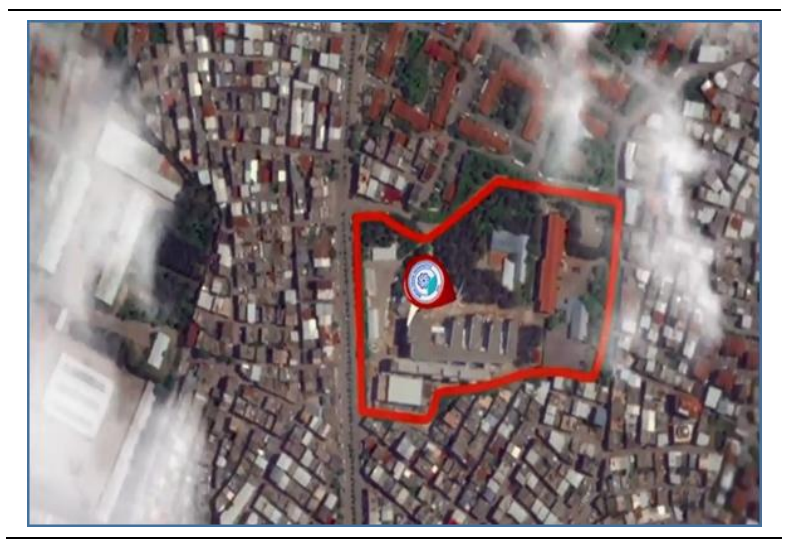


Filmde anlatımın sadece dış ses aracılığı ile gerçekleştirildiği ve herhangi bir diegetik sese rastlanmadığı görülmektedir. Bu durum da filmin belgesel yapıdan, kurgusal yapıya yaklaşmasına yol açmaktadır. Tanıtım filmlerinde bütün anlatımın, her şeyi bilen bir üst anlatıcı ses tarafından gerçekleştirilmesi hem inandırıcılık sorununa yol açmakta hem de paydaşlar ve izleyenler arasında etkileşim olanağını ortadan kaldırmaktadır.

Resim 10. Şehrin Ulaşım Olanakları

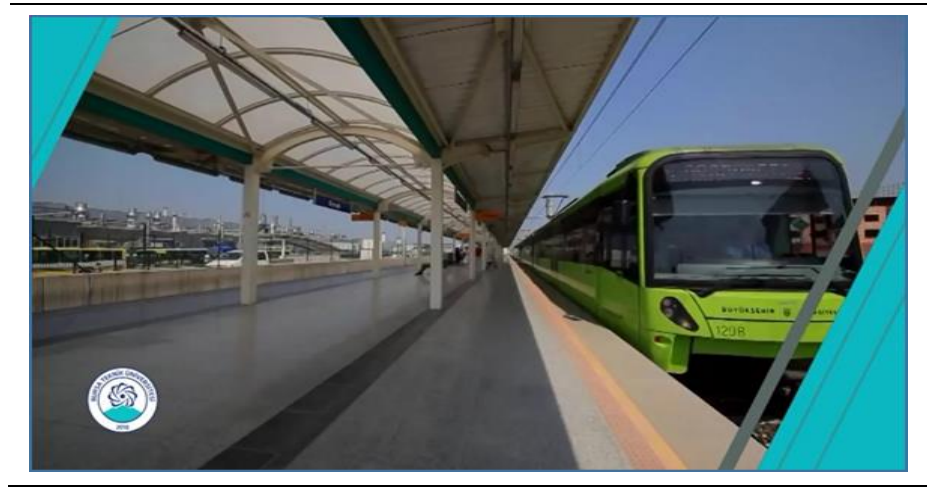

Yapılanma aşamasında olan üniversitelerde göze çarpan bir diğer unsur, paydaşlardan öğretim elemanlarına yapılan vurgunun öğrencilerden fazla olmasıdır. Bu durum öğretim üyesi yeterliliğini göstermeye yönelik bu girişim olarak değerlendirilebilir. Yabancı dil eğitimi ve uluslararası standartlara uygunluk vurgulanmaktadır. Resim 11 'de dersliğin köşesine yerleştirilmiş olan kamera, öznel bir görüş açısını kullanmakta, izleyiciyi dersliğin doğal akışına dışarıdan bakan bir konuma yerleştirmektedir. Eğitim hayatının günlük rutini içinde vurgulanan yabanc1 uyruklu hocalar ile yabancı dil eğitimi söylem olarak burada kalmakta ve ulus üstü, evrensel herhangi bir değere atıf yapılmamaktadır.

Resim 11. Yabancı Dil Eğitimi

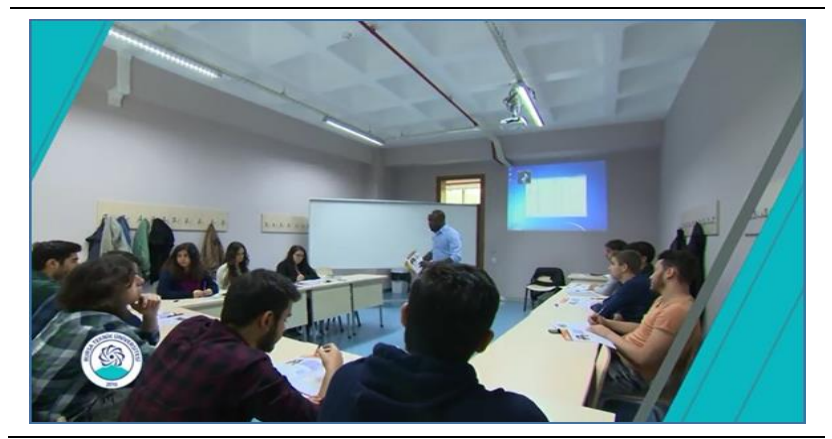

Öğretici kadrosuna ek olarak görselleştirmede bürokratik hiyerarşi ve ilişkilere de vurgu yapılmaktadır. Üniversite yönetim kadrosunun görselleştirildiği Resim 12 film içinde dikey kamera hareketi ile görselleştirilmekte ve ast-üst ilişkisini vurgular nitelikte kullanılmaktadır. Buna ek olarak "U" tipi oturma düzeni tam olarak ortalanarak vurgulanmış ve hiyerarşinin tepesi, çerçevede kurulan üçgenin tepesine yerleştirilmiştir. 
"U” tipi oturma düzeni demokratik bir yapı içerisinde hiyerarşinin net olarak belli olduğu bir düzendir. Buna ek olarak karede kurulan üçgen kompozisyon bürokratik piramide yapılan vurguyu güçlendirmektedir.

Resim 12. Hiyerarşik Yap1

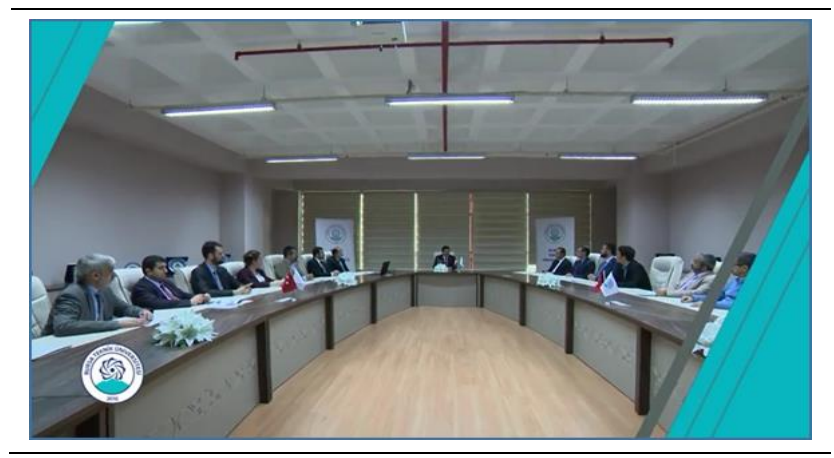

BTÜ örneğinde (diğer üniversite örneklerinde de benzer uygulamalar mevcuttur) şehir bürokrasisi ile kurulan ilişki, ayırt edici bir özellik olarak vurgulanmaktadır. Resim 13 'te görüldüğü üzere Üniversite yönetimi şehrin sivil veya asker bürokratları ile birlikte görselleştirilmekte, bu ilişkiler tanıtım filminde vurgulanmaktadır. Bu durum altyapı sorunlarını çözmeye çalışan yapılanma aşamasındaki üniversitelerin, şehir yönetiminin desteğine duyduğu ihtiyaçtan kaynaklanmaktadır. Normal koşullar altında bir üniversite tanıtım filminin hedef kitlesi o üniversitenin potansiyel öğrencileri ve onların aileleri olarak kabul edilebilir. Bu, hedef kitleyi ilgilendirmeyen bürokratik ilişki vurgusunun, şehrin altyapı olanaklarından yararlanmak isteyen üniversite yönetimlerinin paydaşlara yönelik bir halkla ilişkiler faaliyeti olarak kabul edilebilir. Üniversiteler yerleşiklik kazandıkça, bürokratik ilişkilere yapılan vurgunun tanıtım faaliyetlerinden çıkacağı kabul edilebilir.

Resim 13. Bürokratik İlişkiler

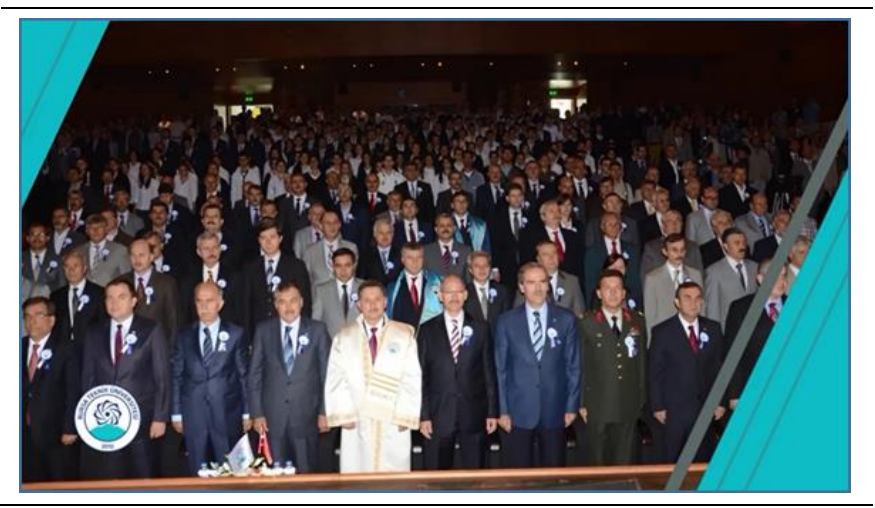

Öğrencilerin üniversite eğitimleri sırasında, aldıkları eğitimler, öğrendikleri bilgisayar programları, yaptıkları projeler ve stajlarla işverenin aradığı kişilere dönüşeceklerinden bahsedilmektedir. Tanıtım filmi "Bilimi geleceğe taşıyan yenilikçi devlet üniversitesi”" 
sloganıyla sona ermektedir. Ancak ekranda "yenilikçi devlet üniversitesi” kısmı yazıyla vurgulanmıştır. Buradan hareketle özellikle büyük şehirlerde yeni kurulan devlet üniversitelerinin öğrenciler tarafından vakıf üniversiteleri ile karışması söz konusu olabileceği endişesinin taşındığından bahsedilebilir.

\subsection{Koç Üniversitesi}

Finansmanı devlet tarafindan sağlanmayan vakıf üniversitelerinde en önemli kaynak öğrencilerin aldıkları eğitim karşılığında ödedikleri ücret olmaktadır. Bu durum üniversitelerin söylemini farklılaştırmaktadır.

Koç Üniversitesi tanıtım filmi (2013) tematik unsurlarıyla bir bütün olarak incelendiğinde popüler bir anlatımın filme hâkim olduğu ve tanıtım filminin, reklam söylemine yaklaştığ görülmektedir. Filmin anlatımı diegetik olmayan elektronik bir müzik eşliğinde gerçekleştirilmektedir. Müziğin türü ve yüksekliği bir fon müziği olmanın dışında bir anlatım unsuru olarak belirmektedir. Bu elektronik müzik, yine diegetik olmayan bir anlatıcı ile birlikte kullanılmıştır. Bu tanıtım filminde dış ses belgesel film dilinde olduğu gibi konuyu veya nesneyi anlatmamakta, seyirciyi bilinçli olarak yönlendirmeye yönelik kurgusal bir yapı sergilemektedir. Olaylar, konular ve üniversite hakkında öznel yorumları belirgin bir biçimde yapan bu dış ses, paydaşların diegetik anlatımlarıyla desteklenmekte ve reklamcılık kavramsallaştırmasında "sonuçtan etkilenme durumuna göre kaynak kullanımı” örneğini oluşturmaktadır. Dış sesin belirgin yönlendirişi, elektronik müzikle birleşerek reklam filminin kurgusal dünyasına yaklaşmaktadır. Üniversite olanakları olarak; kampüs, oryantasyon süreci, çift ana dal, sosyal sermaye, akademisyenlere yakınlık gibi unsurlar bu diegetik olmayan sesin yönlendirdiği sekanslarda öğrenciler tarafından özne olarak anlatılmaktadır. Filmde yer alan tüm unsurların hedef kitle olarak öğrencinin merkeze konduğu ve onun bakış açısına göre söyleme döküldüğü görülmektedir.

Resim 14. Popüler Bir İkonografi Olarak UGG Botlar

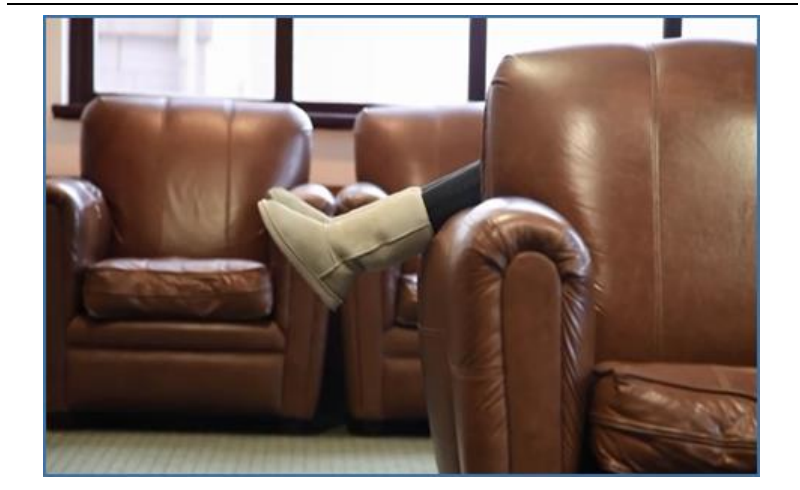

Filmde görülen bir diğer önemli unsur eğlenceli gençlik, rahatlık, sosyallik gibi kavramların gerek süre gerek içerik olarak ön plana çıkmış olduğudur. Resim 14 filmin açılış sekansında kullanılmıştır. Burada gösterilen olarak deri koltuklar ve UGG marka botlar karşımıza çıkmaktadır. Her iki nesnede yan anlamları güçlü olan nesnelerdir. Deri 
koltuklar rahatlık ve lüksü çağrıştırmaktadır. UGG marka botlar ise gençlikle özdeşleşmiş sembolik nesnelerdir. Pop yıldızları tarafından çok tercih edilen bu botlar sosyal medya paylaşımları ile küresel bir üne kavuşmuş; gençlik, rahatlık, özgürlük gibi simgesel bir fetişe dönüşmüştür.

Resim 15. Yazı Tipinin Kullanımı

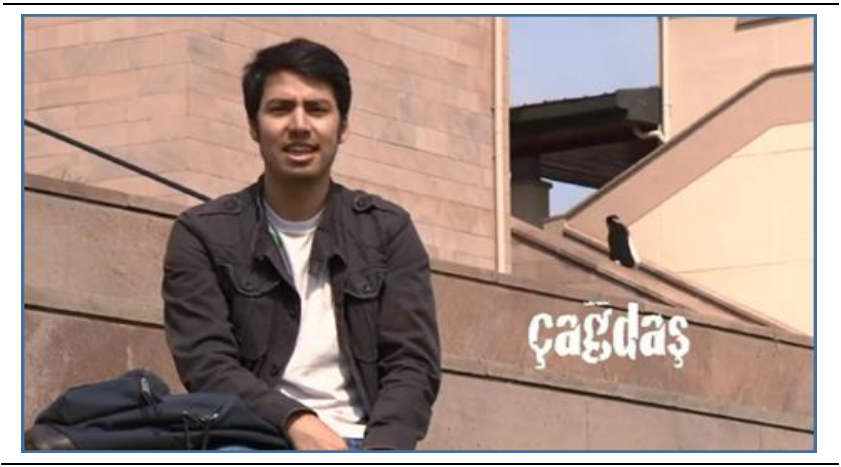

Filme hâkim olan popüler unsurlar yazı tipi ile de desteklenmiştir. Resim 15'da görüldüğü gibi üniversite mimarisi ritmik ve paralel çizgileriyle derin bir arka plan oluşturmaktadır. Bu paralel çizgiler mimari derinliği artırırken, zamansal sürekliliği de vurgulamaktadır. $\mathrm{Bu}$ arka planın önünde bir paydaş olarak öğrenci üniversitesini anlatmaktadır. Ancak burada en önemli unsur yazı tipi olarak belirmektedir. Tanıtım filmi boyunca düzenli font ailelerine ait olmayan, popüler ikonografiden alınmış bir yazı tipi kullanılmıştır. Film boyunca üniversitenin mimarisi derin ve güçlü bir beton blok olarak kullanılmış, ön planda ise elektronik müzik ve "pop" bir yazı türü ile gençlik "motifi”" yer almıştır.

Resim 16. Yabancı Öğretim Üyesi Gösterimi

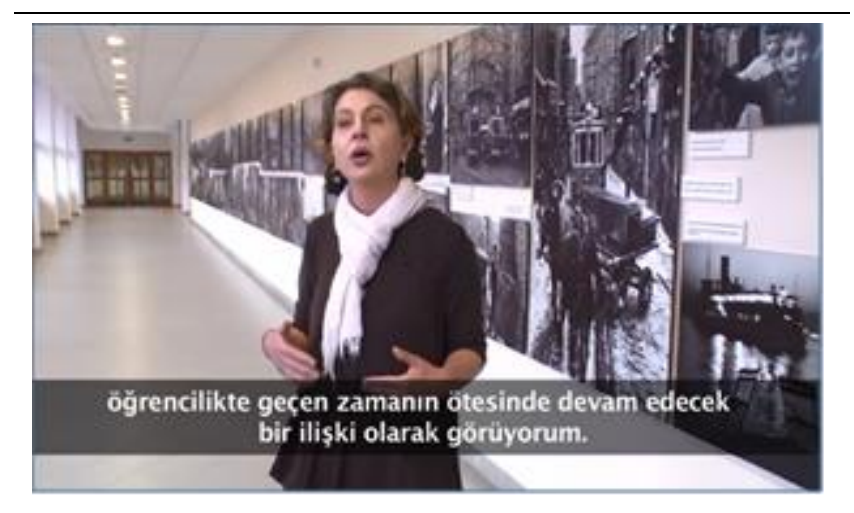

Yurtdışı ile ilişkiler bu filmde de belirgin bir unsur olarak ortaya çıkmaktadır. Birçok mezun öğrenci, dünyanın önde gelen üniversitelerinde aldıkları lisansüstü eğitimlerinde Koç Üniversitesi'nin payını vurgulamakta ve Koç Üniversitesi’nde alınan lisans eğitimini “yurtdışı lisansüstü eğitim” için önemli bir kapı olarak vurgulamaktadır. Yabancı öğretim üyeleri bu tanıtım filminde de anlatıma dâhil edilmiş ancak tanıtım filminin söylemine 
uygun olarak, öğrenci ile yakın ilgi bağlamında öznelleştirilmiştir. Resim 16 'da görüldüğü gibi yabanc1 öğretim üyesi Koç Üniversitesi’nin köklü kurumsal yapısını vurgulayan siyah beyaz resimler önünde görselleştirilmiş̧ir. Siyah beyaz fotoğraf sergisi ve oluşturulan derin perspektif bu köklülüğe vurguyu arttırmaktadır. Ancak burada yabanc1 öğretim üyesi bilimden, üniversiteden ya da Türkiye'den değil öğrenci ile kurduğu ilişkiden bahsetmektedir. Öğrencilerin hocalarıyla rahatça ilişki kurabilmesi tanıtım filmi boyunca birçok kez vurgulanmıştır (bkz Resim 17).

Resim 17. Akademisyen Öğrenci Etkileşimi

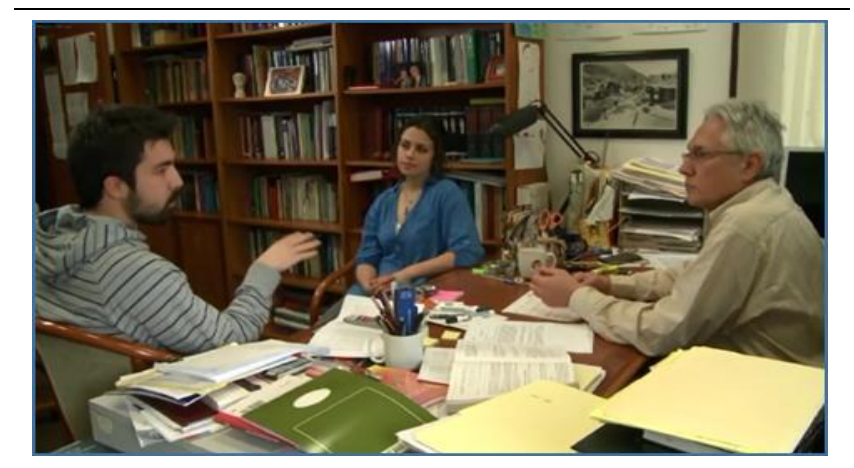

Popüler ikonografi ve öğrenciye yönelik hizmet ve eğitim vurgulandıktan sonra bilimsel çalışmalar işlenmiş ancak bu görselleştirme de popüler ikonografiye yaklaştırılmıştır. Çalışmalar görselleştirilirken bilimsel görselleştirmenin ağır simgeleştirmelerinden, karmaşık laboratuvar ve anlaşılmaz cihazlardan uzak durulmuştur. Öğrencilerle birlikte yapılan çalışmalar ile akademisyenler tarafından alınan patentlerin anlatıldığı sahnede akademisyen ve öğrenci birlikteliği vurgulanmakta, akademisyenin elinde tuttuğu kahve kupası bilimsel çalışma ile gündelik yaşamı birbirine yaklaştırmaktadır (Resim 18). Böylece bilimsellik ve laboratuvar hedef kitle olarak öğrenciye yaklaştırılmış ve katı normatif yapısından uzaklaştırılmıştır.

Resim 18. Bilimsel Çalışmada Akademisyen-Öğrenci Gösterimi

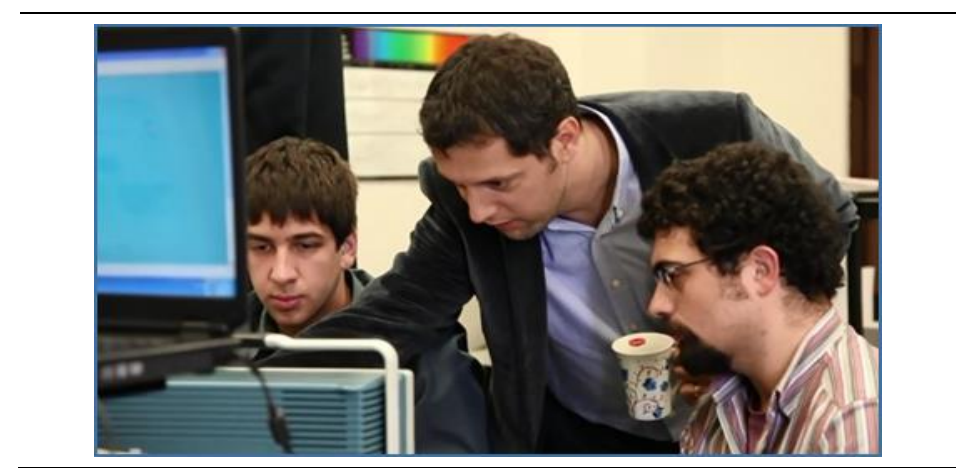

Üniversitede yapılan projelerden, bu projelerin disiplinler arası olmasından bahsedilmiştir. Yapılan projeler ve sonunda alınan patentlerin öğrencilerle birlikte 
alındığı vurgulanmıştır. Araştırmaları ideallerle ilişskilendirmektedirler. İş bulma ve yurtdışı eğitim olanakları üzerindeki vurgu yoğundur. Üniversite öğrencilerine gelecekteki belirsizliklere karşı çok yönlü gelişme, yeni koşullara uyum kabiliyeti kazandırma iddiasındadır.

Resim 19. Kampüs-Doğa Gösterimi

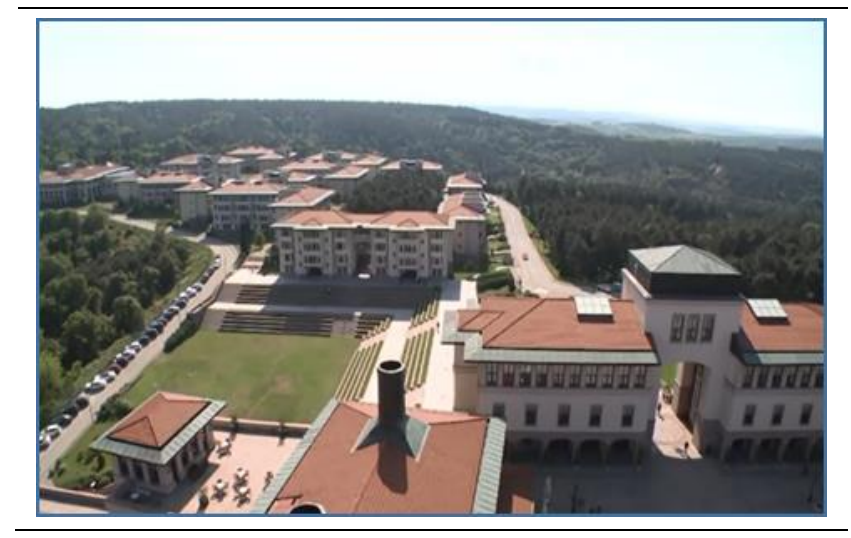

Kampüs ve yurt olanakları vurgulanırken yine öğrenci merkezli bir dil kullanılmış ve eğlence, imkânlar, sosyal aktiviteler yoğun olarak vurgulanmıştır. Burada kampüs yapısına yönelik vurgu önemli bir boyut kazanmaktadır. Resim 19'de görüldüğü üzere yerleşkenin yapısı ve doğa içinde oluşu vurgulanmakta ve yine görselden anlaşıldığı üzere yerleşkenin şehir dışında ve doğa içinde kendine yeten bir yap1 oluşu vurgulanmaktadır. Yerleşke İstanbul'da olmasına rağmen İstanbul'un kimlik ve olanaklarına yönelik hiçbir vurgu yoktur. Şehir dışında bulunmak olumlu bir unsur olarak ön plana taşınmaktadır.

\subsection{Hasan Kalyoncu Üniversitesi}

Hasan Kalyoncu Üniversitesi 2008 yılında Gaziantep ilinde kurulmuş bir vakıf üniversitesidir. Üniversite yapılanma aşamasında olduğu için belirgin bir kurumsal kimliği oluşmamıştır. Bu durumun tanıtım filmine de (Hasan Kalyoncu Üniversitesi, 2015) yansıdığı görülmektedir.

Öncelikli olarak anlatım dilinden bahsetmek gerekmektedir. Tanıtım filminde seyirciyi yönlendiren herhangi bir anlatıcı söz konusu değildir. Bu da anlatımı nesnel kılmakta, diagetik olmayan anlatıcının yönlendirici etkisinden seyirciyi kurtarmaktadır. Bu durumda söylemin filmografi aracılığı ile kurulması gerekmektedir. Ancak tanıtım söylemi yeterlilikleri vurgulamakta, kurumsal kimliği zaman boyutunda herhangi bir perspektife yerleştirmemektedir. 2000 sonrası kurulan üniversitelerde, özellikle büyükşehirdeyse şehrin olanaklarının vurgulanarak üniversiteye olumlu bir katkı olarak kullanıldığı görülmektedir. Ancak Hasan Kalyoncu örneğinde böyle bir kullanıma rastlanmamakta, hatta üniversitenin yer aldığ 1 şehir dahi belirtilmemektedir. Tanıtımın bütün çerçevesi yerleşke ve olanakları ölçeği ile sınırlandırılmıştır. Resim 20, filmin kurucu sekansından bir karedir. Binalar, yeşil alan ve sportif alanların birlikte sergilendiği 
bu kare yerleşke ve üniversitenin fiziksel yeterliliğini ve altyapısının tamamlandığını görselleştirmeye yöneliktir.

Resim 20. Hasan Kalyoncu Üniversitesi Kampüsü

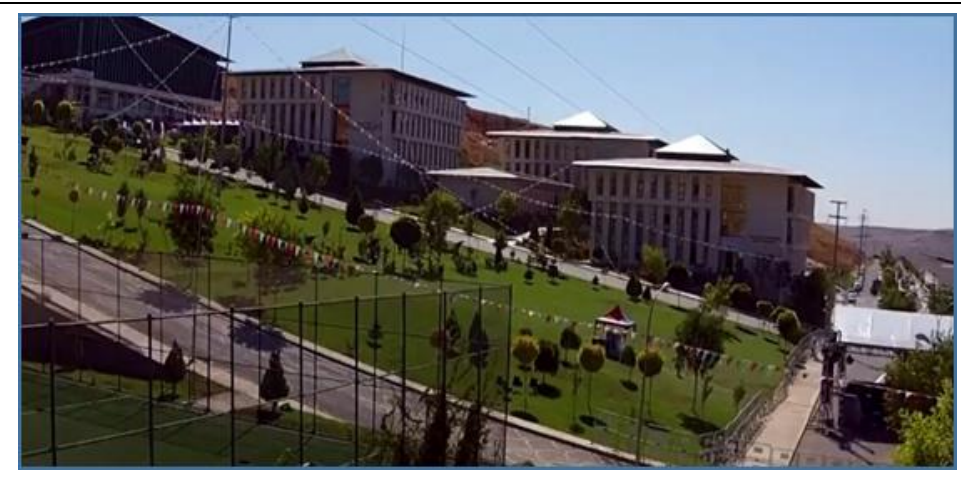

Bir fon müziği eşliğinde diagetik öğrenci anlatımlarıyla sürdürülen metin, bölüm ve üniversitenin anlatıldığı, olanakların gösterildiği bir filmografi ile devam etmektedir. Derslik, laboratuvar gibi klasik eğitim, öğretim anlatısının arasında yabancı dil eğitimi ve yabancı uyruklu öğretim üyesi vurgusu göze çarpmaktadır (Resim 21). Metinde uluslararası ya da evrensel herhangi bir değere ya da hedefe atıfta bulunulmamakta, yabancı dil eğitiminde yabancı uyruklu öğretim elemanlarının varlığının altı çizilmektedir. Derslik, laboratuvar gibi olanaklara eklemlenen yabancı uyruklu öğretim üyesi vurgusu, eğitim standardını belirtmeye, uluslararası nitelikte bir eğitim yapıldığı söylemini üretmeye yöneliktir. Bu noktada yabancı uyruklu öğretim üyesi kavramının araçsallaştı̆̆ı, eğitimde uluslararası yeterlilik ispatının simgesel değerini üstlendiği söylenebilir.

Resim 21. Yabancı Uyruklu Öğretim Üyesi

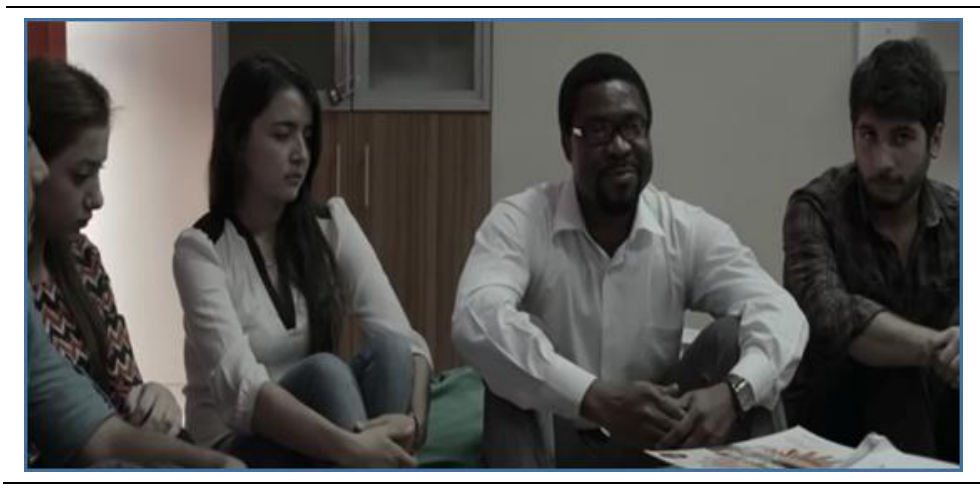

Tanıtım filminde göze çarpan bir diğer önemli unsur, üniversite yönetimi ile siyaset dünyası ilişkisidir. Daha önce de belirtildiği gibi 2000 sonrası kurulan üniversiteler altyapı yatırımlarında bürokrasi ve siyaset dünyasının katkılarına ihtiyaç duymaktadır. 
Hasan Kalyoncu Üniversitesi örneğinde de bir halkla ilişkiler faaliyeti olarak üniversite yönetimi ve siyaset dünyası üyeleri bir arada görselleştirilmiştir (Resim 22).

Resim 22. Üniversite Yönetimi ve Siyaset İlişkisi

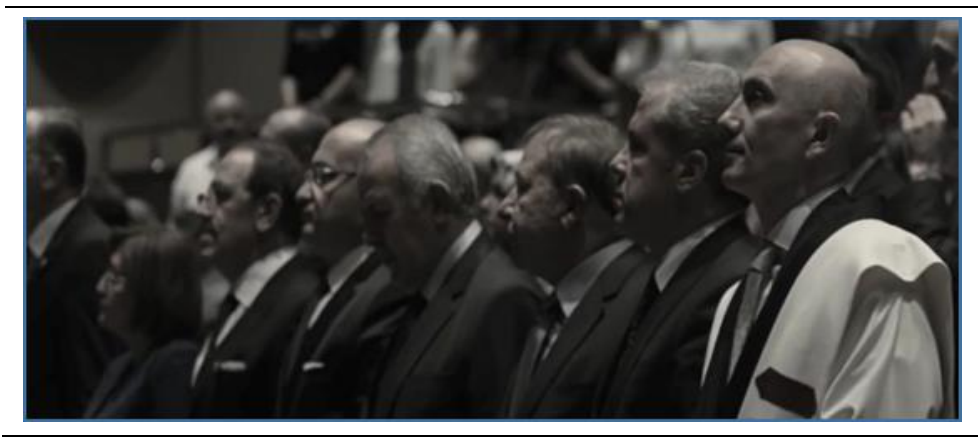

Üniversite yerleşkesi ve yeterliliklerinin gösteriminin ardından sosyal etkinlikler çerçevesinde gençler tarafından yakından takip edilen birkaç pop yıldızı görselleştirilmiş ve gençlerin eğlence görüntüleri ile birlikte kurgulanmıştır. Resim 23 bu popüler şenlik görüntülerini kaydedip, görselleri sosyal medyada paylaşan bir gençlik ikonografisini temsil etmektedir. Zaman olarak geçmiş ve gelecek arasında bir perspektif oluşturmayan söylem, mekân olarak da kampüs dışında herhangi bir şeye atıf yapmamakta, özyeterlilikleri sergileyerek söylemini oluşturmaktadır. Kampüs, yeşil alan ve mimarinin yoğun olarak vurgulandığı filmografinin temel olarak, eğitim öğretim yeterliliklerini vurgulamakla sınırlandığı bunun üzerinde herhangi bir iddiada bulunmadığı söylenebilir.

Resim 23. Gençlik ve Popüler Kültür

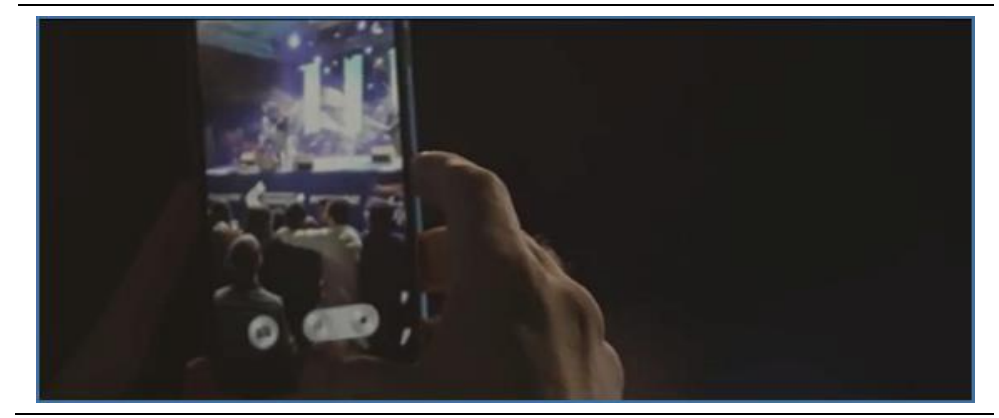

\subsection{Cumhuriyet Üniversitesi}

Cumhuriyet'in kuruluşunun 50. y1lı anısına Sivas şehrinde kurulmuş olan Üniversite'nin isim ve logosu doğrudan Türkiye Milliyetçiliğine atıf barındırmaktadır. Buna ek olarak daha önceki devlet üniversitelerinde görülen açılış sekansında üniversite ve Türk Bayrağ1 birlikteliğinin, Cumhuriyet Üniversitesi (2016) tanıtım filminde de devam ettiği görülmektedir (Resim 24). 
Resim 24. Cumhuriyet Üniversitesi

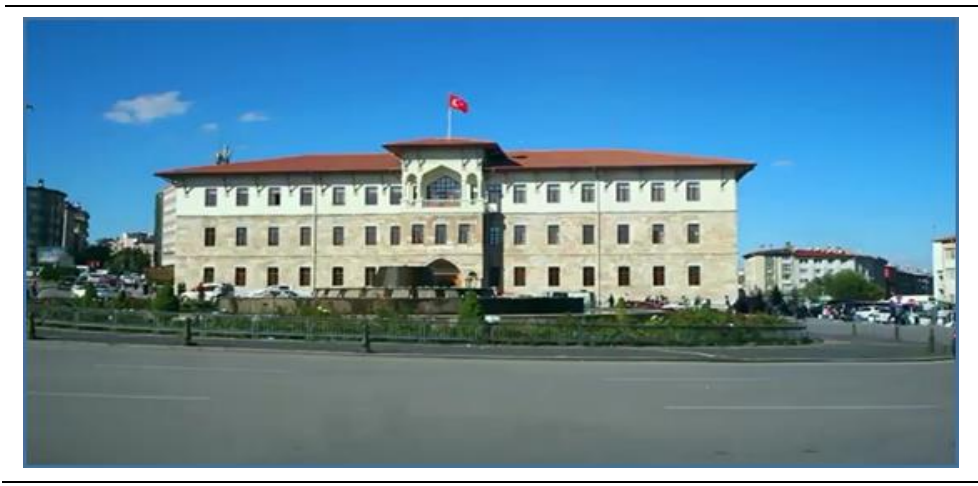

Cumhuriyet Üniversitesi tanıtım filmi söylem olarak büyük şehirlerde kurulu olan üniversitelerin dışında bir çizgi izlemektedir. Öncelikli olarak anlatım tamamen diagetik olmayan bir dış sesle yürütülmekte ve hiçbir paydaş diagetik olarak filme dâhil edilmemektedir. Şehir ve üniversitenin köklü geçmişine yönelik kısa bir giriş sahnesinin ardından (Resim 25), anlatım üniversite olanaklarına yönelmekte ve film baştan sona üniversite olanaklarının gösterilişi ile devam etmekte ve sonlanmaktadır.

Resim 25. Cumhuriyet Üniversitesi ve köklü geçmişi

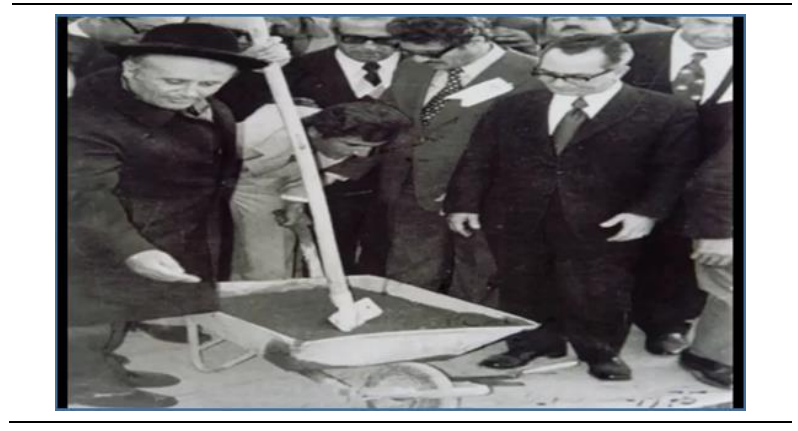

Üniversite olanaklarının anlatıldığı bölümlerde bütün fakülteler ve bölümlerin tanıtımının ardından Tıp Fakültesi, Diş Hekimliği Fakültesi ve Veterinerlik Fakültesi ayrı olarak anlatılmakta, Tıp fakültesi ve Veterinerlik fakültesinin bölgesel öneminin altı çizilmektedir. Söylemde üniversite olanak ve laboratuvarlarından daha çok Tıp Fakültesinin başarıları ve olanakları sergilenmektedir (Resim 26). Bu sekansta üniversitenin misyonu dile getirilmektedir. Tıp fakültesi ve Veterinerlik fakültesinin bölgesel önemi, Anadolu Selçukluları Uygulama ve Araştırma Merkezi, Tarım ve Hayvancılık Uygulama ve Araştırma Merkezi'nin kırsal kalkınma açısından önemi ve Teknokent'in Sivas ve çevresi için önemi vurgulanmaktadır. Cumhuriyet Üniversitesi kendisini tamamen Sivas ve çevresinin ihtiyaçlarına verdiği cevap ve bölgesel kalkınmada oynadığı rol ile tanımlamaktadır. Araştırma merkezleri, üniversite sanayi işbirliği çalışmaları, Ar-Ge merkezleri tanıtımda yer alan unsurlardır. 
Resim 26. Cumhuriyet Üniversitesini Temsilen Tıp Fakültesi

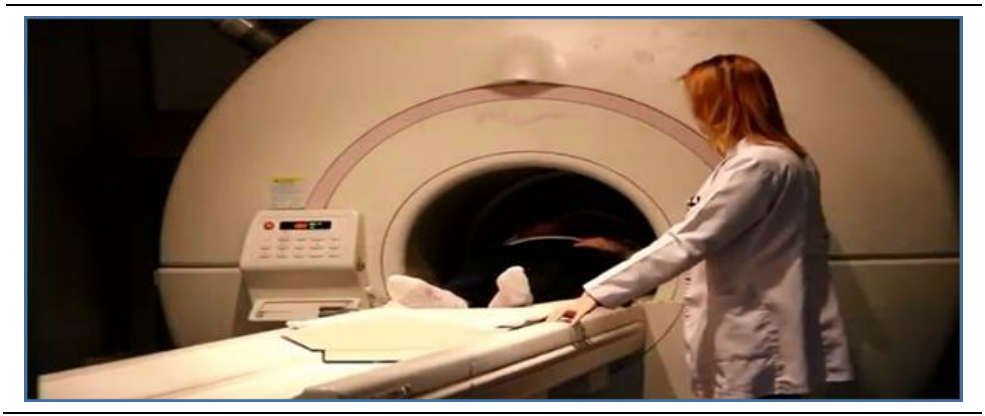

Anlatım esnasında dâhil olunan uluslararası değişim programları ile öğretim üyesi ve öğrenci değişiminden bahsedilse de filmografide bu konuya yer verilmemekte, anlatımda da önemli bir yer işgal etmemektedir. Büyük şehirlerde kurulu olan üniversiteler, büyük şehrin olanaklarını kurumsal kimliğine dâhil etmeye çalışırken, Cumhuriyet Üniversitesi örneğinde üniversitenin şehre olanak ve hizmet aktarımının vurgulandığı görülmektedir. Sonuç olarak Cumhuriyet Üniversite'sinin söylemde ulusal kalkınmanın yerel temsilcisi olarak konumlandığı görülmektedir.

\subsection{Yalova Üniversitesi}

Hem Yalova'nın hem de Yalova Üniversitesi'nin hukuksal statüleri son derece yenidir. Yalova 1995 y1lında il olmuş, Yalova Üniversitesi' de 2008 y1lında kurulmuştur. Yalova diğer küçük illere nazaran coğrafi koordinatı nedeniyle büyükşehirlerin arasında bulunmakta ve birçok olanağı bünyesinde barındırmaktadır. Bu çerçevede Yalova Üniversitesi tanıtım filmi (2015) yeni kurulan üniversitelerin yaşadığ 1 kurumsal söylem oluşturamama durumunu devam ettirmektedir. Tanıtım filmi üniversiteden önce şehrin olanaklarından bahsetmekte ve genel söylemde de şehrin olanaklarının, üniversite kimliğine aktarılmaya çalışıldığı görülmektedir (Resim 27). Şehrin yeşilliği, denizin varlığı, ulaşım kolaylığı ve sosyal olanaklarının tamamı üniversite kimliğine dâhil edilmektedir.

Resim 27. Mutlu Yalova - Şehir ve Üniversite kimliği

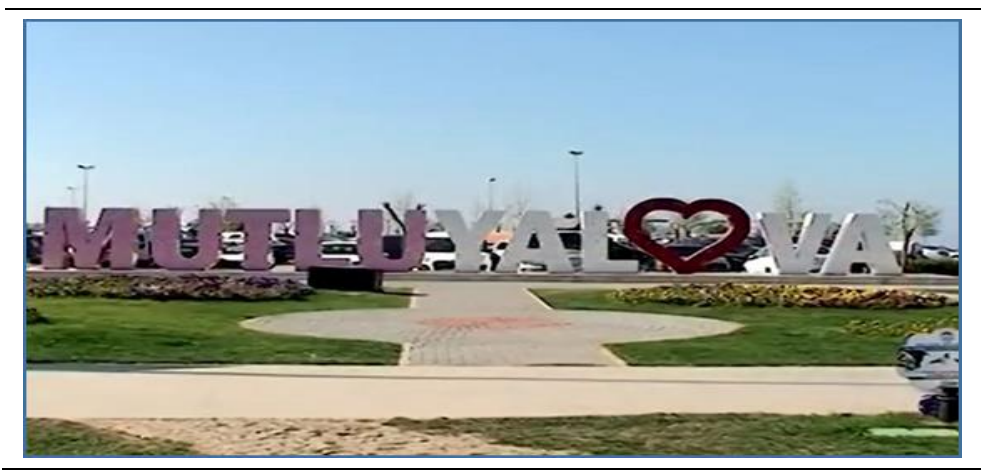


Yalova Üniversitesi henüz yerleşke inşaatını tamamlayamadığı için geçici binalarda eğitim hayatını sürdürmektedir. $\mathrm{Bu}$ nedenle kampüs görselleri bilgisayar ortamında oluşturularak kullanılmıştır (Resim 28). Bu noktaya kadar incelenen tüm devlet üniversitesi tanıtım filmlerinin açılış sekansında üniversite kimliği ile Türk Bayrağı arasında analojik bir bağ kurduğu vurgulanmıştı. Kampüs görüntülerini bilgisayar tasarımı ile oluşturan Yalova Üniversitesi tanıtım filminde de bu durum aynı biçimi ile devam etmektedir.

Resim 28. Yalova Üniversitesi yerleşkesine yönelik 3 boyutlu tasarım

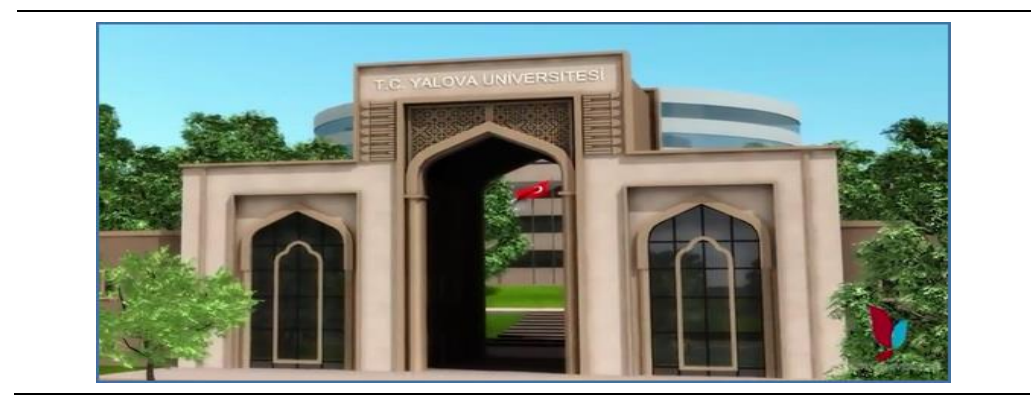

Anlatımı yönlendiren herhangi bir dış ses yoktur ancak üniversite olanakları, bölümleri ve diğer unsurları yazı ile belirtilmiştir. Altyapı yetersizliğinin filmografiye izin vermemesi nedeniyle yazı ve animasyonun ağırlıklı olarak kullanıldı̆̆ görülmektedir. $\mathrm{Bu}$ noktada şehrin olanakları vurgulandıktan sonra, üniversitenin olanakları değil, değerleri sıralanmakta üniversite kimliği bu değerler üzerinden üretilmeye çalışılmaktadır.

Anlatımı desteklemek için sık sık öğrenciler diagetik olarak metine dâhil edilmiş ve üniversiteyi onların ifade etmesi sağlanmıştır. Ancak bütün öğrenci anlatıcılar "üniversitenin yeniliğine rağmen şehrin ve üniversitenin sunduğu olanaklardan" bahsetmektedir. Bu da üniversitenin henüz yapılanma aşamasında olduğunu örtülü olarak göstermektedir. Yalova şehrinin olanaklarından ve üniversitenin değerlerinden bahseden söylem ulusal ya da ulus üstü herhangi bir hedefe yönelmemekte bütün söylem, yeniliğe rağmen var olan olanaklar çerçevesinde kurulmaktadır. Bu bağlamda geçmiş ve gelecek arasında bir kimlik oluşturulamamakta, film öz yeterlilik sorunsalı etrafında dönmektedir.

Resim 29. Yabancı Uyruklu öğrenciler

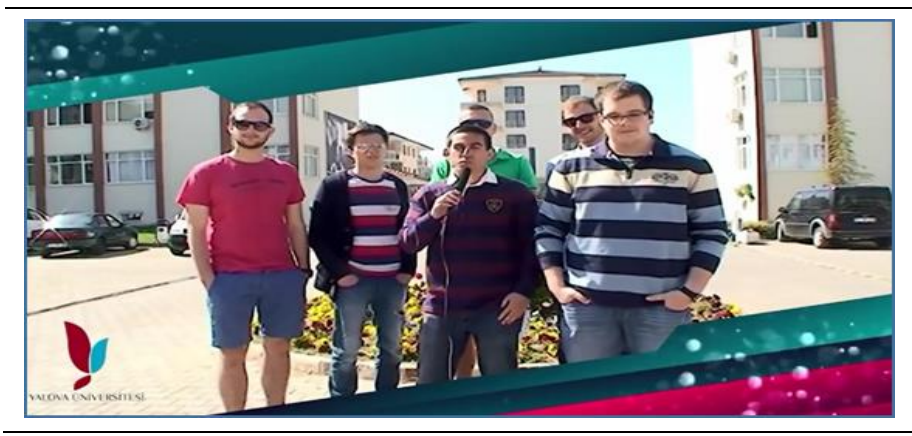


$\mathrm{Bu}$ noktada son olarak değişim programı ile gelen yabancı öğrenciler görselleştirilmektedir. Ancak bu kullanım gerek görsel kompozisyonda gerek kurgusal kompozisyonda herhangi bir konuma yerleşmemektedir. $\mathrm{Ne}$ anlatımda ne de görselleştirmede üniversite ya da eğitimle ilişkilendirilmeyen bu kullanım yabancı uyruklu öğrencileri salt bir varlık olarak konumlandırmakta, var oldukları için görselleştirmektedir (Resim 29). Herhangi bir bağlama yaslanmayan bu kullanım, yabancı uyruklu öğrencilerin "Mutlu Yalova" sloganıyla son bulmaktadır. Şehir ile başlayan anlatım, yine şehir ile kapanmaktadır.

\section{SONUÇ}

Bu çalışmada üniversitelere yönelik tanıtım filmleri incelenmiş ve söylem düzeyinde belirli eğilimlerin olduğu görülmüştür. Öncelikli olarak tüm devlet üniversiteleri filmin açılış sekansında Türk Bayrağına yer vermiş ve kurumsal kimlikleri ile ulusal kimlik arasında bir bağ kurmuşlardır. Buna karşın vakıf üniversitelerinde açılış sekanslarında vurgunun kampüs olanaklarında olduğu görülmektedir.

Vakıf üniversiteleri ile devlet üniversiteleri arasındaki bir diğer önemli ayrım, vakıf üniversitelerinin anlatımda popüler imgelere daha çok yer veriyor oluşudur. $\mathrm{Bu}$ durum içeriğe yansıdığı gibi, Koç Üniversitesi örneğinde olduğu gibi anlatımın kendisini de oluşturabilmektedir.

2000 yılından sonra kurulan üniversitelerde şehrin olanaklarını üniversiteye aktarmak yaygın bir eğilim olarak ön plana çıkmaktadır. Bursa Teknik ve Yalova Üniversitesi filmlerinin açılışlarını şehrin olanakları ile yaparken, bir vakıf üniversitesi olarak Hasan Kalyoncu Üniversitesi şehrin olanaklarından hatta hangi şehirde olduğundan dahi bahsetmemektedir. Vakıf üniversitelerinin şehirden çok kampüs olanaklarını vurgulamaya eğilimli oldukları görülmektedir. $\mathrm{Bu}$ durum bu üniversitelerin büyükşehirlerde kurulu olmalarından ve aynı şehirde rekabet etmeleri gereken devlet üniversiteleri olmasından kaynaklanıyor görünmektedir. Şehirdeki diğer üniversitelerden farklılaşmayı sağlamayacak mesajların verilmesi, vakıf üniversiteleri ücretli eğitim verdikleri için anlamlı değildir. Ancak devlet üniversiteleri bu özelliklere vurgu yaparak o şehirde okumak isteyen öğrencilerin tercih listelerine girmeyi başarabilirler.

ODTÜ ve Koç gibi büyükşehirlerde kurumsallaşmış köklü üniversiteler şehirden bahsetmemekte, hatta Koç Üniversitesi şehir dışılığı vurgulamaktadır. Buna karşın yeni kurulan üniversiteler şehrin kendilerine kattığı değerlerden bahsederken, 2000 yılı öncesinde kurulmuş olmasına rağmen büyükşehir dışında yapılanan Cumhuriyet Üniversitesi kendisinin yerele olan katkısını ön plana çıkarmaktadır.

Büyükşehirlerde var olan üniversitelerden 2000 öncesi kurulanlar mimari ve doğa arasındaki uyumu ön plana çıkarırken, 2000 sonrası kurulanlar yapılanmayı ve binaları vurgulamaktadır. Küçük şehirlerde var olan üniversiteler ise mimari ve doğa arasındaki ilişkiye değinmemekte, beton blok, bina ve teknik olanak gösterimini ön plana taşımaktadır.

2000 yılı sonrası kurulan üniversitelerde üniversite yönetiminin, siyaset ve bürokrasi dünyası ile ilişkisi tanıtım filmlerinde belirgin bir biçimde vurgulanırken, kurumsal kimliği oluşmuş köklü üniversitelerde bu tür kullanımlara yer verilmediği görülmektedir. 
$\mathrm{Bu}$ durumun bilimsel çalışmalardan ziyade altyapı eksiklikleri ile uğraşan yeni üniversitelerin devlet ve yerel yönetim katkısına duyduğu ihtiyaçtan kaynaklandığı söylenebilir.

Uluslararasılık, yurtdışı ve evrensellik bütün tanıtım filmlerinde söyleme dökülmektedir. Ancak her üniversite kurumsal misyonunu farklı bir çerçevede çizmektedir. Kendini Türkiye modernleşmesinin öncüsü olarak kurgulayan ODTÜ yurtdışı ile ilişkilerini, evrensel dünyaya etki eden bir özne olarak konumlandırmaktadır. Koç Üniversitesi ise verdiği eğitimin yurtdışında köklü üniversitelerde lisansüstü eğitimin kapısını açtığını vurgulamakta, ODTÜ'ye göre daha edilgen bir konum tercih etmektedir. 2000 sonrası kurulan üniversiteler yabancı dil eğitimini ve yabancı uyruklu akademisyeni bir yeterlilik enstrümanı olarak kurgularken, kendini yerel kalkınmanın öncüsü olarak konumlandıran Cumhuriyet Üniversitesi yurtdışı ile ilişkileri sadece değişim programları ölçeğinde söyleme dökmekte, yerelliği ön plana taşımaktadır.

2000 sonrası kurulan bütün üniversitelerin söylemi öz yeterlilik sorunu etrafinda dönmekte, teknik ve beşerî altyapı söylemde önemli bir yer işgal etmektedir. 2000 öncesi kurulan üniversitelerden ODTÜ evrensel değerlere atıf yapmakta, teknoloji, doğa ve insan birlikteliğini filmografisinde ön plana taşımaktadır. Cumhuriyet Üniversitesi ise ulusal ya da evrensel bir söylem kurmamakta yerel bazda ürettiği hizmet ve bölgesel kalkınmaya sağladığı desteği temel söylem haline getirmektedir. Koç Üniversitesi ise bütün yeterliliklerini vurgulamakta ancak söylemini popüler kültüre uygun bir düzlemde tutarak, eğlence, rahatlık, sosyallik, yurtdışına çıkış gibi araçları kullanarak hedef kitlesine yönelmektedir.

Yıldız (2014: 166) tarafından yapılan çalışmada ön plana çıkan tanıtım vaatleri olan; yurt dışı olanakları, kariyer olanakları, burslar ve nitelikli eğitim ile bu çalışmanın sonuçları kısmen örtüşmektedir. Yurtdışı olanakları ve eğitimin niteliği (bazı durumlarda eğitim için gerekli olanakların yeterliliği) tüm tanıtım filmlerinde konu edilmiştir. Ancak kariyer olanaklarına tüm üniversitelerde rastlanmamıştır. Burslar ise tanıtım filmlerinde oldukça az değinilen bir konu olmuştur. Bu farklılıklar tanıtımın yapıldığg mecradan ve Yıldız'ın çalışmasındaki örneklemin daha çok vakıf üniversitelerinden oluşmasından kaynaklanıyor olabilir.

Belirtildiği gibi söylem, biz kavramını değerler, örgüt üyeleri, ötekilerin kim olduğu, amaçların ne olduğu gibi sorular etrafında örerek üretir. 2000 sonrası kurulan tüm örneklerde bu sorulara üretilen cevapların belirsiz olduğu görülmektedir. Henüz eylem ve motivasyon değil; varlık ve yeterlilik vurgusu genel durum olarak belirmektedir. 2000 öncesi kurulan üniversiteler ise bu sorulara cevap üretebilecek bir söylem üretmektedir. Bir vakıf üniversitesi olarak Koç Üniversitesi normatif değerlere sınırlı atıf yaparken, öğrenci rahatlığı ve mutluluğunu merkezi bir değer olarak ön plana taşımaktadır. Büyükşsehir dışında konumlu Cumhuriyet Üniversitesi bölgesel kalkınmayı varlık amacı olarak belirlerken, Ankara konumlu ODTÜ küresel sistemi etkileyen/dönüştüren Türkiyeli bir temsilci olmayı kimliğinin temel motivasyonu olarak göstermektedir.

Üniversite tanıtım filmleri arasında oluşan söylem farklılıkları kamu-vakıf ve 2000 öncesi-sonrası olarak Tablo 1 ve Tablo 2'de gösterilmiştir. Büyükşehir ve büyükşehir dışı ayrımına yönelik söylem farklılıklarının diğer iki kategori altında kaybolduğu 
görülmektedir. Bu bağlamda söylem farklılığını temel olarak üniversitenin tüzel kişilik yapısı ve kuruluş yılı üzerinden belirginleştiği ortaya çıkmaktadır.

Tablo 2. İncelenen Tanıtım Filmlerinde Kamu - Vakıf Üniversitesi Söylem Farklılıkları

\begin{tabular}{lll}
\hline & & \multicolumn{1}{c}{ Kamu } \\
\hline Türk Bayrağı Vurgusu & Belirgin & Belirsiz \\
Hedef kitleye değer önerisi & Eğitim, sorumluluk, toplum vurgusu & Eğlence, tesis, hizmet \\
Şehir vurgusu & Var & Yok \\
Film dilinde popüler kültür & Yok & Var \\
\hline
\end{tabular}

Tablo 3. İncelenen Tanıtım Filmlerinde Kuruluş Yılına Göre Söylem Farklılıkları

\begin{tabular}{|c|c|c|}
\hline & 2000 öncesi & 2000 sonras1 \\
\hline & Geçmiş ve gelecek (zaman vurgusu) & $\begin{array}{l}\text { Gelecek, tesis kalitesi } \\
\text { (mekan vurgusu) }\end{array}$ \\
\hline Bürokrasi-siyaset ilişkisi & Yok & Var \\
\hline Teknoloji vurgusu & Doğa ve insan ilişkili ile var & Ilișkisiz olarak var \\
\hline Bina ve tesis vurgusu & Doğa ve insan ilişkili ile var & Ilişkisiz olarak var \\
\hline Küresel etki & Belirgin (büyükşehir üniversiteleri) & Belirsiz \\
\hline Hedef kitle değer önerisi & $\begin{array}{l}\text { Ulus üstü vaatler (büyükşehir } \\
\text { üniversiteleri) } \\
\text { Bölgesel kalkınmada etkin rol } \\
\text { (büyükşehir dışı) }\end{array}$ & Eğitimde yeterlilik \\
\hline Şehir vurgusu & Yok & Belirgin \\
\hline $\begin{array}{l}\text { Yabanc1 konumlandırılış1 } \\
\text { (öğrenci-öğretim üyesi) }\end{array}$ & $\begin{array}{l}\text { Küresel etkileşim ilişkisi içinde } \\
\text { (Büyükşehirde olanlarda) }\end{array}$ & $\begin{array}{l}\text { Eğitim yeterliliği ilişkisi } \\
\text { içinde }\end{array}$ \\
\hline
\end{tabular}

$\mathrm{Bu}$ çalışma altı üniversitenin tanıtım filmlerinin analizinden oluşmaktadır. Bundan sonraki çalışmalarda üniversiteler bütünleşik pazarlama iletişimi açısından ele alınabilir. Tanıtım filmleri, reklamları, sosyal medyadaki paylaşımları, internet siteleri, halkla ilişkiler faaliyetleri, rektörlerin verdikleri mesajlar vb. birlikte ele alınarak üniversitelerin pazarlama iletişimlerindeki başarılar değerlendirilebilir.

\section{KAYNAKÇA}

Altunışık, R., Özdemir, Ş., \& Torlak, M. (2016). Pazarlama İlkeleri ve Yönetimi. İstanbul: Beta Yayınları.

Babacan, M. (2015). Nedir Bu Reklam. İstanbul: Beta Yayınları.

Binbaşığlu, H. (2011). Yükseköğretimde Eğitim Hizmetlerinin Pazarlanması: Bir Pilot Araştırma. Uluslararası Yüksekögretim Kongresi: Yeni Yönelişler ve Sorunlar. 27-29 Mayıs 2011. İstanbul 3(16), 2465-2474 
BTÜ (2015). Tanıtım Videosu-2015. (Erişim: 10.06.2016) https://www.youtube.com/watch?v=18yLmgY2rJA

Cumhuriyet Üniversitesi (2016). Tanıtım Videosu-2016. (Erişim: 10.06.2016) https://www.youtube.com/watch?v=F727DyxHxGU

Dijk, T. V. (2015). Söylem ve İdeoloji: Çokalanlı Bir Yaklaşım. B. Çoban, \& Z. Özarslan içinde, Söylem ve İdeoloji (s. 15-100). İstanbul: Su Yayınları.

El-Nawawy, M., \& Elmesry, M. H. (2016). The Signs of a Strongman: A Semiotic and Discourse Analysis of Abdelfattah Al-Sisi's Egyptian Presidential Campaign. International Journal of Communication, (10), 2275-2296.

Fiske, J. (2015). İletişim Çalı̧̧malarına Giriş. (çev. S. İrvan) Ankara: Pharmakon Yayınları.

Günay D., \& Günay A. (2011). 1933'den Günümüze Türk Yükseköğretiminde Niceliksel Gelişmeler. Yükseköğretim ve Bilim Dergisi, 1(1), 1-22

Hasan Kalyoncu Üniversitesi (2015). Tanıtım Videosu-2015. (Erişim: 10.06.2016) http://www.hku.edu.tr/TanitimFilmleri/Tanitim-Filmleri/3/0/

Hemsley-Brown, J., \& Oplatka, I. (2006). Universities in a competitive global marketplace: A systematic review of the literature on higher education marketing. International Journal of Public Sector Management, 19(4), 316-338.

Kavak, Y. (2011). Türkiye'de Yükseköğretimde Büyüme: Yakın Geçmişe Bakış ve Uzun Vadeli (2010-2050) Büyüme Projeksiyonları. Yükseköğretim Dergisi, 1(2), 95-102.

Koç Üniversitesi (2013). Tanıtım Videosu-2013. (Erişim: 10.06.2016) https://www.youtube.com/watch?v=ApOT-qnyzVo

Kotler, P., \& Keller, K. L., (2009). Marketing Management. (13th edition). Pearson.

Marangoz, A. Y., \& Arslan, F. M. (2015). Üniversitelerin Pazarlanmasında Tutundurma Boyutu: Kavramsal Bir İrdeleme. Toros Üniversitesi IISBF Sosyal Bilimler Dergisi, 2(4).

Newman, S., \& Jahdi, K. (2009). Marketisation of education: Marketing, rhetoric and reality. Journal of Further and Higher Education, 33(1), 1-11.

ODTÜ (2014). Tanıtım Videosu - 2014. (Erişim: 10.06.2016) https://www.youtube.com/watch?v=PhloPGb1vO4

Okumuş, A., \& Duygun, A. (2008). Eğitim hizmetlerinin pazarlanmasında hizmet kalitesinin ölçümü ve algılanan hizmet kalitesi ile öğrenci memnuniyeti arasındaki ilişki. Anadolu Üniversitesi Sosyal Bilimler Dergisi, 8(2), 17-38.

Sakınç, S., \& Bursalığlu, S. A. (2012). Yükseköğretimde küresel bir değişim: Girişimci üniversite modeli. Journal of Higher Education \& Science/Yüksekögretim ve Bilim Dergisi, 2(2), 92-99.

Sözen, M. F. (2013). Yapısalcı Yöntem ve Bir Film Çözümlemesi. International Journal of Social Science, 6(9), 609-629. 
Vural, Z. B., \& Bat, M. (2013). Kurumsal İletişim. İstanbul: İletişim Yayınları.

Yalova Üniversitesi (2015). Tanıtım Videosu - 2015. (Erişim: 10.06.2016) https://www.youtube.com/watch?v=Nu-OIeWUVsQ

Yenen, V. Z., \& Gözlü, S. (2003). Yüksek öğretimde müşteri beklentileri: Türkiye'den örnekler. ITÜUDERISII/d, 2(2), 28-38.

Yıldız, S. (2014). Üniversiteler Ne Vaat Ediyor? Türkiye'deki Üniversitelerin Basın İlanları Üzerine Bir İçerik Analizi. Anadolu University Journal of Social Sciences, 14(2), 155-170.

YÖK (2016). Yükseköğretim Kurumu İstatistikleri. (Erişim: 08.04.2016), https://istatistik.yok.gov.tr/

Yücebaş, M. (2011). İdeolojik Bir Süreç Olarak Operasyonel Üniversiteden Girişimci Üniversiteye: Yeni Üniversitenin Reklam İmgeleri. İletişim: Araştırmaları, 5(1), 3974.

Tekin, M., \& Çiçek, E. (2005). İşletmelerde Rekabet Üstünlüğü Sağlamada Farklı Bir Yaklaşım: Değer Temelli Pazarlama. V. Ulusal Üretim Araştırmaları Sempozyumu, Istanbul Ticaret Üniversitesi. 63-68.

Trout, J., (2005). Geleceğin Pazarlamacısı İçin Konumlandırma Stratejileri. (çev. Ümit Şensoy). İstanbul: Optimist Kitap. 